\title{
Seasonal variability of Holocene climate: a palaeolimnological study on varved sediments in Lake Jues (Harz Mountains, Germany)
}

\author{
Ricarda Voigt · Eberhard Grüger • \\ Janina Baier - Dieter Meischner
}

Received: 9 December 2006/Accepted: 28 March 2008/Published online: 14 May 2008

(C) The Author(s) 2008

\begin{abstract}
Studies combining sedimentological and biological evidence to reconstruct Holocene climate beyond the major changes, and especially seasonality, are rare in Europe, and are nearly completely absent in Germany. The present study tries to reconstruct changes of seasonality from evidence of annual algal successions within the framework of well-established pollen zonation and ${ }^{14} \mathrm{C}$-AMS dates from terrestrial plants. Laminated Holocene sediments in Lake Jues $\left(10^{\circ} 20.7^{\prime} \mathrm{E}, 51^{\circ} 39.3^{\prime} \mathrm{N}, 241 \mathrm{~m}\right.$ a.s.1.), located at the SW margin of the Harz Mountains, central Germany, were studied for sediment characteristics, pollen, diatoms and coccal green algae. An age model is based on 21 calibrated AMS radiocarbon dates from terrestrial plants. The sedimentary record covers the entire Holocene period. Trophic status and circulation/ stagnation patterns of the lake were inferred from algal
\end{abstract}

R. Voigt $(\bowtie) \cdot$ E. Grüger

Albrecht-von-Haller-Institut für Pflanzenwissenschaften, Abteilung für Palynologie und Klimadynamik, Universität Göttingen, Untere Karspüle 2, 37073 Göttingen, Germany e-mail:voigt.buss@snafu.de

J. Baier · D. Meischner

Geowissenschaftliches Zentrum, Universität Göttingen,

Goldschmidtstraße 3, 37077 Göttingen, Germany

Present Address:

J. Baier

GeoForschungsZentrum Potsdam, Sektion 3.3:

Klimadynamik und Sedimente, Telegrafenberg,

14473 Potsdam, Germany assemblages, the subannual structure of varves and the physico-chemical properties of the sediment. During the Holocene, mixing conditions alternated between di-, oligo- and meromictic depending on length and variability of spring and fall periods, and the stability of winter and summer weather. The trophic state was controlled by nutrient input, circulation patterns and the temperature-dependent rates of organic production and mineralization. Climate shifts, mainly in phase with those recorded from other European regions, are inferred from changing limnological conditions and terrestrial vegetation. Significant changes occurred at 11,600 cal. yr. BP (Preboreal warming), between 10,600 and 10,100 cal. yr. BP (Boreal cooling), and between 8,400 and 4,550 cal. yr. BP (warm and dry interval of the Atlantic). Since 4,550 cal. yr. BP the climate became gradually cooler, wetter and more oceanic. This trend was interrupted by warmer and dryer phases between 3,440 and 2,850 cal. yr. BP and, likely, between 2,500 and 2,250 cal. yr. BP.

Keywords Palaeolimnology - Holocene climate . Diatoms · Green algae $\cdot$ Pollen $\cdot$ Karst

\section{Introduction}

Despite decades of research, there are still many open questions concerning the variability of the Holocene climate in Central Europe. Reasons are uncertain chronologies, large distances between investigated 
sites, and lack of understanding of the regional effects of climate change, especially of changing seasonality.

The climate of Central Europe is grossly transitional between four major, neighbouring regimes: (i) Maritime or Oceanic (North Atlantic), (ii) Continental (Eurasian), (iii) Sub-arctic and (iv) Mediterranean:

\begin{tabular}{lll}
\hline Wet & $\begin{array}{l}\text { Warm } \\
\text { Oceanic }\end{array}$ & \multicolumn{2}{c}{ Cool } \\
& & Subarctic \\
Dry & Mediterranean & Contral Europeantal \\
\hline
\end{tabular}

The actual Central European climate is highly variable regionally and temporally. As is typical for the temperate zone, four seasons are generally expressed. Usually, summer and winter have more stable, higher atmospheric pressure weather, whereas the transitional seasons are changeable. Due to the disrupted topography of the continent, lasting changes of the hemispheric circulation do not simply result in latitudinal shifts of the climate zones, but may have different effects even in neighbouring regions. This constrains the correlation of different palaeoclimatic reconstructions over great distances.

Further, reliable chronologies are essential for precise reconstruction of environmental changes and are prerequisites for the distinction between climatic and local environmental effects, when compared to other palaeo-archives. Many otherwise detailed palaeo-reconstructions suffer from uncertain chronologies (e.g. Nesje et al. 2000; Seppä and Birks 2001; Wennrich 2005) and are therefore not readily available for exact comparison. Radiocarbon dating should preferably be done on terrestrial macrofossils. Bulk sediment ages remain questionable as locally and temporally changeable reservoir effects can be compensated for by wiggle matching at best (van Geel et al. 1996).

Especially in Germany, reliably dated palaeoclimate reconstructions are still rare with the exception of studies of vegetation history. Pollen data allow researchers to reconstruct former types of vegetation from which some climatic conditions can be derived. More detailed information about the former climate, however, can only be gained by combined analysis of additional proxies. In Germany, only five palaeoecological reconstructions-covering the entire Holocene-are well dated, four of them on varved sediment sequences and one on oak tree-ring chronologies (Holzmaar: Baier et al. 2004; Brauer et al. 2001; Lücke et al. 2003; Zolitschka 1998; Zolitschka et al. 2000; Meerfelder Maar: Brauer et al. 2001; Lake Steisslingen: Eusterhues et al. 2002, 2005; Hämelsee: Kleinmann et al. 2000a, b; River Main: Spurk et al. 2002).

Hence, there is an urgent need for a closer-meshed net of well-dated studies in Germany to distinguish not only between warmer and cooler but also between drier and wetter phases. Moreover, the effects of climate change on the seasonality, especially on the transitional seasons, should be considered. So far, only a few palaeolimnological studies have addressed seasonal changes (e.g. Baier et al. 2003; Bradbury and Dieterich-Rurup 1993; Köster and Pienitz 2006; Lotter and Bigler 2000; Schmidt et al. 2007; Rautio et al. 2000).

With the present study, we try to fill the gap between the better investigated regions of Switzerland, France and Scandinavia (Berglund 2001; Eronen et al. 1999; Haas et al. 1998; Hammarlund et al. 2005; Hormes et al. 2001; Magny 2004; Tinner et al. 2003). This paper focuses on aquatic vegetation, including diatoms, green algae, and hydrophytes, on sediment characteristics and on the former terrestrial vegetation to derive, from their changes, limnological and climatic shifts.

The sediments in Lake Jues, situated in the Harz forelands, a region already well investigated in pollenanalytical respects (Beug 1992; Beug et al. 1999; Chen 1988), were chosen for this study. The record from this lake is especially suitable for environmental reconstructions because of its high and constant sedimentation rates throughout the entire Holocene, the annual laminations, the very sensitive climatecontrolled circulation pattern, and the excellent preservation of biological indicators in the sediment. Sediment characteristics and accumulation rates are determined by climate and human impact only, because the catchment of the lake is small and has not changed during the Holocene except for the last few centuries. Sufficient amounts of macrofossils from terrestrial plants allow excellent AMS radiocarbon dating.

Organic annual laminations in lake sediments (varves) can only develop when there are seasonal climatic differences, and when nutrients and temperatures are sufficient for lacustrine biogenic production (Saarnisto 1986). Varves are preserved 
when bioturbation is prevented due to at least temporary anoxia in the hypolimnion. The latter is favoured by oligo- or meromixis, but can also develop in eutrophic holomictic lakes (Zolitschka 1998). Annual climate, especially the length and variability of spring and fall periods, determines the circulation pattern and, in turn, the development of plankton and the trophic status of a lake. As biogenic varves consist of the seasonal succession of algal-mainly diatomblooms (spring, summer and autumn layers) and a detritus layer (late autumn and winter), they reflect variations of the seasonal climate. Diatoms are highly sensitive to changes in nutrients, $\mathrm{pH}$ and salinity ( $\mathrm{Smol}$ and Cumming 2000) and, thus are reliable tools for long-term environmental reconstructions, including annual and subannual varve analysis. Annually varved lake sediments sensitively reflect environmental changes at high time resolution and are ideal subjects for palaeo-reconstructions beyond the mere registration of wetter/dryer or warmer/cooler phases.

\section{Study site}

Physiography, geology and climate

Lake Jues is situated at the SW-margin of the Harz Mountains (Central Germany, Figs. 1, 2). The Harz Mountains, rising to $1,142 \mathrm{~m}$ a.s.l., form a natural barrier to the north and to the east. They consist of Palaeozoic greywacke, shale and chert folded during the Hercynian orogeny. Upper Permian Zechstein formations lapping onto the folded basement consist of several hundred metres of alternating dolomite and anhydrite. The Permian rocks extend along the margin of the Hercynian basement in a kilometrewide depression (Fig. 2). The evaporitic rocks are heavily karsted and pierced by thousands of sinkholes.

Lake Jues fills two overlapping sinkholes, which formed after the collapse of a cave in the $40 \mathrm{~m}$ thick Z1 ("Werra")-anhydrite, at the end of the last glaciation (Fig. 3). With an original volume of more than $2.5 \mathrm{M} \mathrm{m}^{3}$ the Jues sinkholes rank among the biggest of this kind in Germany (Teichmann 1986).

The environs of Lake Jues are dominated by Quaternary erosion and accumulation of gravel terraces by the rivers Sieber and Oder, in turn overlain by loess and post-glacial soils (Mohr 1982; Priesnitz 1969). The Lower Triassic Rotenberg sandstone hills

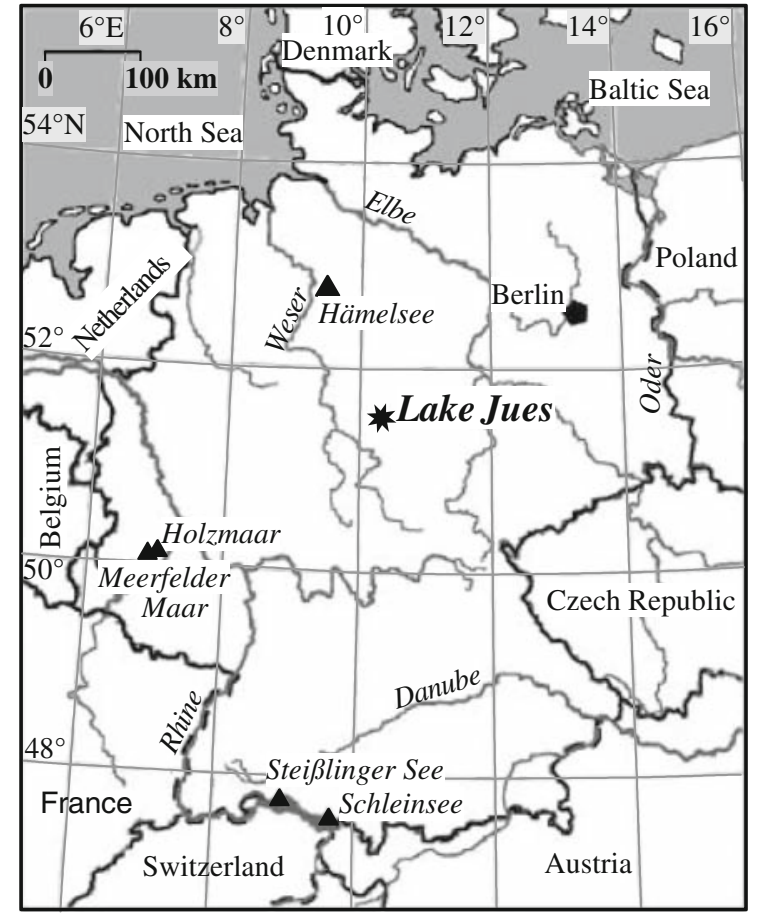

Fig. 1 Map of Germany, locations of Lake Jues and other sites with known Holocene varved sediments

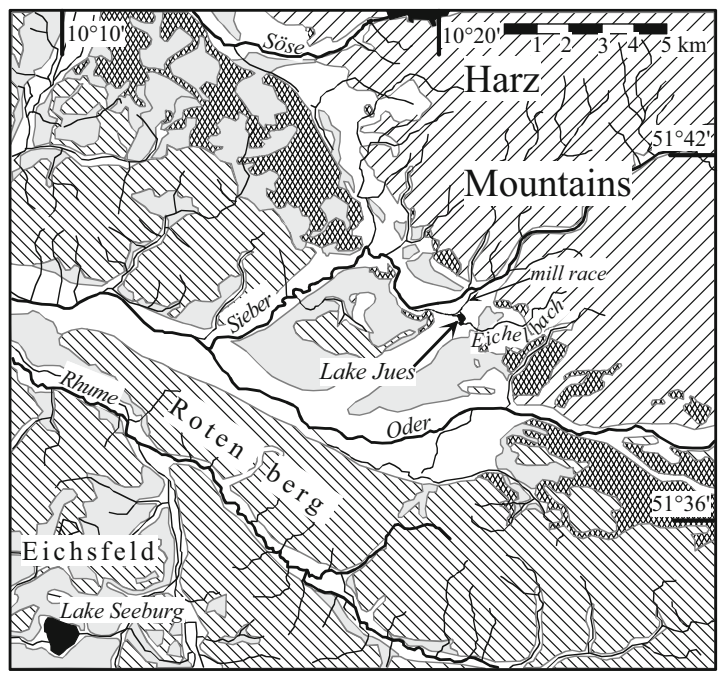

W/ Palaeozoic greywacke, shale
$\begin{aligned} & \square \text { and chert } \\ & \text { Quaternary loess and loess soils } \\ & \text { Permian Zechstein (dolomite, anhydrite) }\end{aligned}$
alluaial soils

Fig. 2 Geological map of the study area (source: Geologische Übersichtskarte der Bundesrepublik Deutschland 1:200,000/ CC 4726 Goslar) 
Fig. 3 Geological section across Lake Jues. Note section is 5 times exaggerated; black: Holocene limnic sediments (modified after Teichmann 1986)

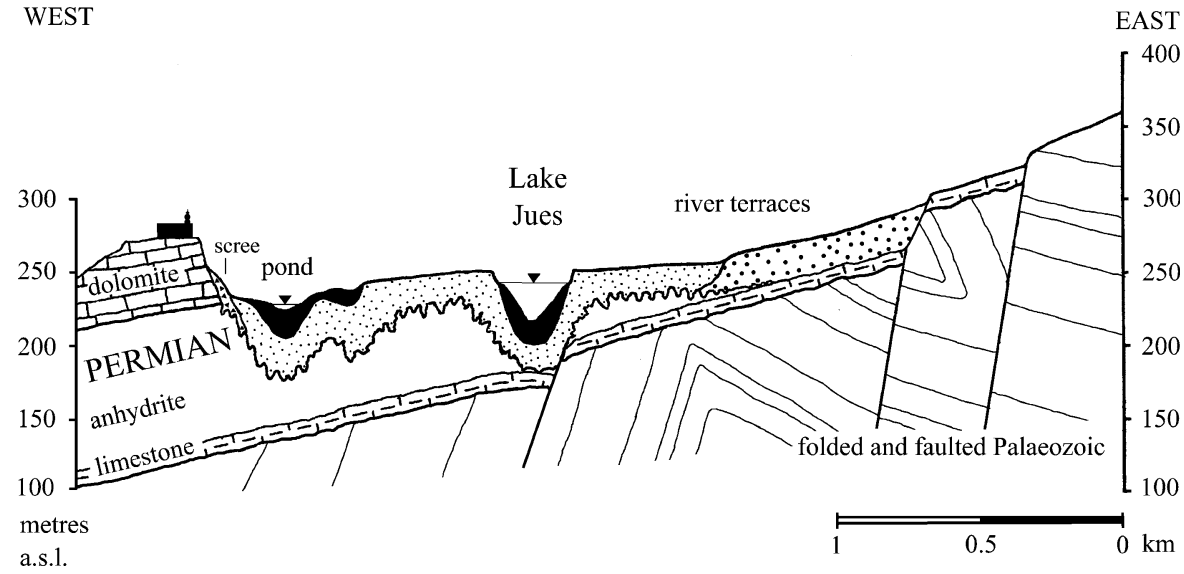

and the rivers Oder and Sieber separate the Jues area from the extended, loess-covered region of the Lower Eichsfeld in the southwest (Fig. 2).

Lake Jues lies amidst the residential town of Herzberg (10,600 inhabitants). Land use around the town is mainly agricultural while Harz Mts. and Rotenberg are wooded.

The area south of the Harz Mts. is situated about the transition between Middle-European oceanic and continental climates. Due to the nearby mountain chain, the local climate is humid with $840 \mathrm{~mm}$ annual precipitation and a slight maximum $(90 \mathrm{~mm} / \mathrm{month})$ during summer. The mean annual temperature is $6-7^{\circ} \mathrm{C}$ with monthly averages of $15-17^{\circ} \mathrm{C}$ in summer and $-1^{\circ} \mathrm{C}$ in January and February. The mean snowcover period $(>1 \mathrm{~cm})$ is 41 days (Glässer 1994).

Current hydrography and limnology

(Table 1, Figs. 4-6)

Lake Jues fills two sinkholes connected through a $50 \mathrm{~m}$ wide passage (Fig. 4). The smaller basin has a surface area of 1.2 ha and a maximum depth of $6.5 \mathrm{~m}$, the large one is $28.5 \mathrm{~m}$ deep and covers an area of 5.6 ha. Today, Lake Jues has one, intermittent inflow, the $5 \mathrm{~km}$ long Eichelbach brook which springs from the folded Palaeozoic (Fig. 2). Passing the karsted Permian rocks, most of this creek's water recedes underground to feed the Rhume spring $10 \mathrm{~km}$ south (Thürnau 1913). The lower end of the Eichelbach is a drainage ditch that was dug to divert the waters of the brook away from two sinkholes, and into the lake (according land-registry office, Osterode). Water from the river Sieber can be supplied to
Table 1 Morphometrical and chemical characteristics of Lake Jues (main basin)

\begin{tabular}{ll}
\hline Coordinates & $10^{\circ} 20.7^{\prime} \mathrm{E}, 51^{\circ} 39.3^{\prime} \mathrm{N}$ \\
Altitude & $241 \mathrm{~m}$ a.s.l. \\
Lake surface & $56,600 \mathrm{~m}^{2}$ \\
Lake volume & $521,000 \mathrm{~m}^{3}$ \\
Average depth & $9.2 \mathrm{~m}$ \\
Maximum depth & $28.5 \mathrm{~m}$ \\
Catchment area & $3.5 \mathrm{~km}^{2}$ (present) \\
Mean pH & $7-8$ \\
Mean conductivity & $190 \mu \mathrm{S} / \mathrm{cm}$ \\
Mean total phosphorus (TP) & $<30 \mu \mathrm{g} / 1^{*}$ \\
Mean total nitrogen & $309 \mu \mathrm{g} / 1$ \\
Mean sulphate & $42 \mathrm{mg} / 1$ \\
\hline
\end{tabular}

The mean values are based on the monthly measurements between November, 1983 and February, 1985, each time at ten different water depths (Teichmann 1986)

* For seasonal distribution and changes see Fig. 6

the lake through the Mühlengraben (mill race) since ca. $1034 \mathrm{AD}$ (according to our sedimentological and AMS-data). A weir-regulated outlet is located at the NW edge of the main basin, leading the water back via the mill race into the river Sieber. During preindustrial times, Lake Jues existed as a groundwater pond, the level changing with that of the surrounding groundwater.

The main sinkhole of Lake Jues has a relatively small surface area, is fairly deep, and has steep sides. Because of this morphometry, the circulation depends strongly on the length and the nature of the spring and fall periods. As a result, Lake Jues is oligomictic with a temporarily anoxic hypolimnion that can reach up to $10 \mathrm{~m}$ or less water depth in summer (Fig. 5). 


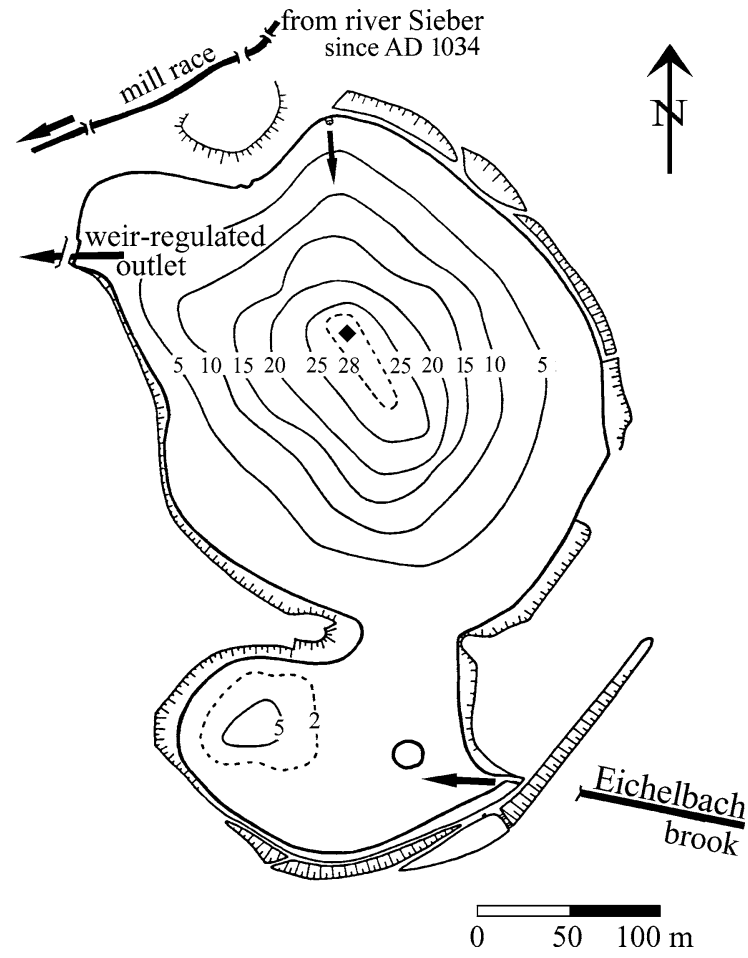

Fig. 4 Bathymetric map of Lake Jues, contours: metres (Teichmann 1986). Diamond: coring stations

Teichmann (1986) surveyed two years of autumnal monomixis between November 1983 and February 1985 at monthly intervals (Figs. 5, 6). At mean phosphorus concentrations lower than $30 \mu \mathrm{g} / \mathrm{l}$ (Table 1), Lake Jues appears to be mesotrophic. However, total phosphorus concentrations vary considerably during the course of one year. Very high epilimnic concentrations (max. $240 \mu \mathrm{g} / \mathrm{l}$ ) were measured during and after circulation periods, whereas the epilimnion was nearly depleted of phosphorus $(<10 \mu \mathrm{g} / \mathrm{l})$ during summer and autumn. Shortly after deep circulation, hypolimnic phosphorus concentrations reach extremes of $1,900 \mu \mathrm{g} / \mathrm{l}$ due to re-dissolution from the sediment. Two temporary superficial phosphorus peaks result from agricultural discharge (October 1984 and February 1985). With secchi-depths of less than $2 \mathrm{~m}$, mass-development of plankton, and epilimnic over-saturation of oxygen, the lake is more appropriately classified as meso- to eutrophic.

Nitrogen concentrations are rather low (Table 1), although nitrogen is not a factor limiting plankton growth in this lake. Sulphate concentrations are quite low, too. At present time, the water body of Lake Jues has apparently little exchange with the groundwater in the surrounding Permian anhydrite and gypsum. However, ammonium and hydrogen sulphide still heavily accumulate in the hypolimnion during long anoxic phases.

The lake is circumneutral with average $\mathrm{pH}$ values of 7.2 during circulation periods, but summer plankton growth results in a strong $\mathrm{pH}$ increase in the epilimnion reaching $\mathrm{pH} 9.4$.

\section{Methods}

Fieldwork and sampling

Five sediment cores were taken from the profundal of Lake Jues in April and June 1995 by means of aluminium tubes on a pneumatic vibration corer (Meischner et al. 1981). The sediment surface was lost in cores JUES 95/4 and JUES 95/7 but is included in the shorter cores which are not compacted by coring. Cores JUES 95/4 and JUES 95/7 (85 mm diameter) were combined to a composite profile for this study using the distinct laminations of the sediments for precise correlation (Fig. 7). All cores were used for studying macroscopic sediment charcteristics.

Subsamples for pollen-analytical and diatomological studies were taken with PVC-syringes. Additionally, continuous sampling for high-resolution pollen analyses was done using sample corers with a square cross section of $11 \times 11 \mathrm{~mm}^{2}$. One centimeter thick sediment slices were taken for macrofossil analysis. Further samples $(10 \mathrm{~cm} \times 2 \mathrm{~cm})$ were taken for thin sections (Table 2).

Cores are stored in Geowissenschaftliches Zentrum, University of Göttingen, Department of Sedimentology, Germany.

Radiocarbon dating

Terrestrial macrofossils and a deer bone were radiometrically dated (AMS method) at the LeibnizLaboratory for Radiometric Dating and Isotope Research of the University of Kiel/Germany (Table 3, Fig. 8). The bone (kia 11824) from core JUES 95/4 plotted about 1,000 years younger than the host sediment. It was probably displaced by the coring process. Another very small sample (kia 3818, $2.8 \mathrm{mg}$ of leaf and wood fragments) obviously dated too old. The age model is based on inter- and extrapolation of 


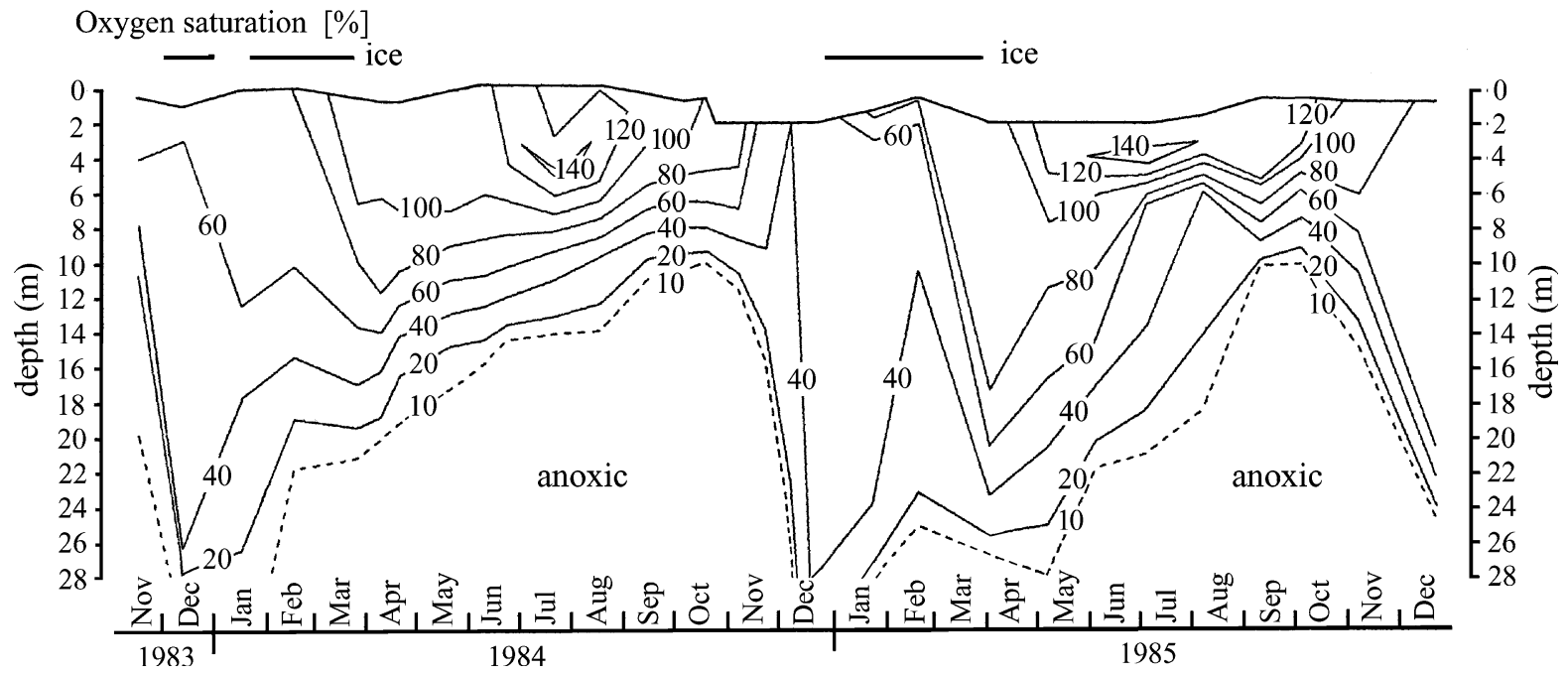

Fig. 5 Oxygen saturation (\%) in Lake Jues, November 1983 through December 1985, iodometric titration acc. to Winkler (1888), isopleths calculated by linear interpolation (Teichmann
1986). Dashed line: not equidistant. Water depth zero denotes the mean water-level (241 m a.s.1.). Note: Spring circulations are incomplete due to late ice covers

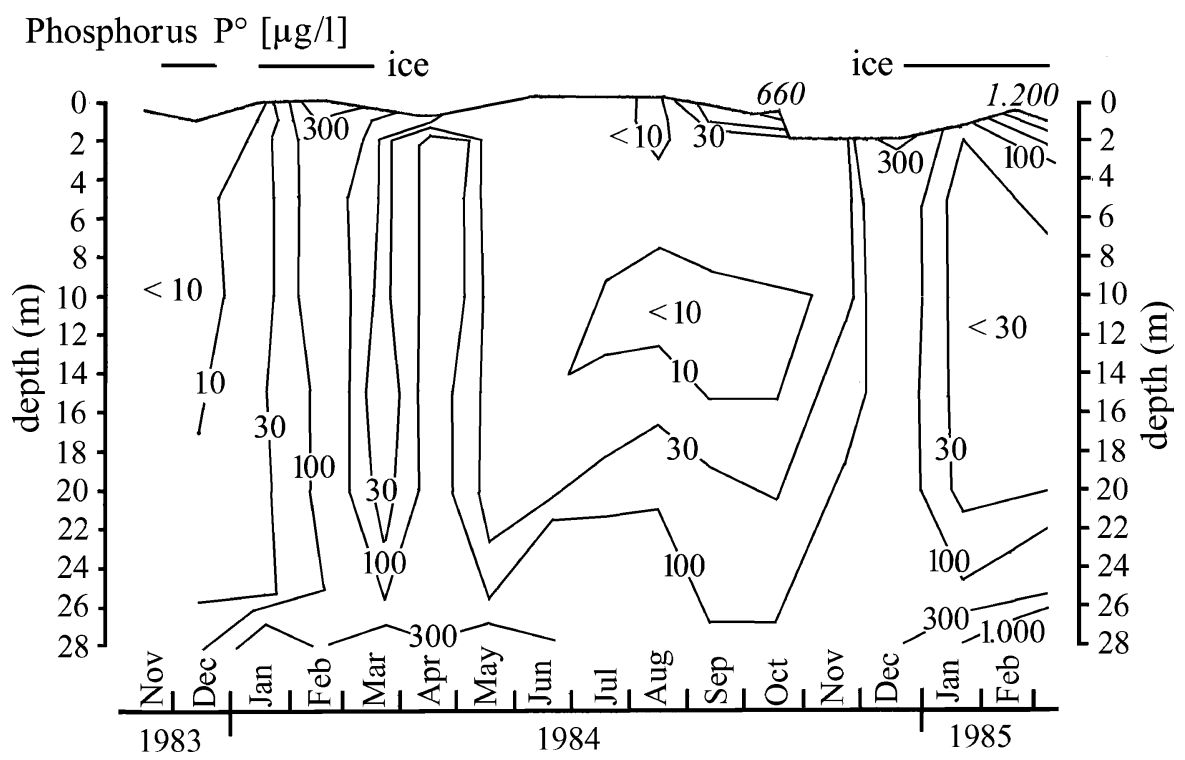

Fig. 6 Total phosphorus concentrations $(\mu \mathrm{g} / \mathrm{l})$ in Lake Jues, November 1983 through December 1985, vanadium-blue photospectrometric method, data recalculated from Teichmann (1986), logarithmic interpolation. Water depth zero corresponds to the mean water-level (241 m a.s.1.). Note high

21 reliable ${ }^{14} \mathrm{C}$-measurements (calibration according to Stuiver et al. 1998). Extrapolation was not done for the Younger Dryas because of the change in sediment type at the transition from Younger Dryas to Preboreal. When the calibration curve yielded more than one fit
P-concentrations in the whole water column subsequent to more or less complete circulation and oxygenation events (cf. Fig. 5) become consumed within short time. Excessively high concentrations in the epilimnion (slant figures) are caused by pollution from local sources

due to a fluctuation in atmospheric ${ }^{14} \mathrm{C}$, the arithmetic mean was used. For the chronological presentation of the results the thick minerogenic layers are excluded, because these are considered to be deposited during very short episodes (extreme weather events). 
Fig. 7 Correlation of cores, sediment types and inter-/extrapolated radiocarbon ages (cal. yr. BP). Depths below sediment surface not corrected for compaction by coring. Vertical lines show the sediment slices used for the composite profile. Stars indicate dated levels. LST $=$ Laacher See Tephra

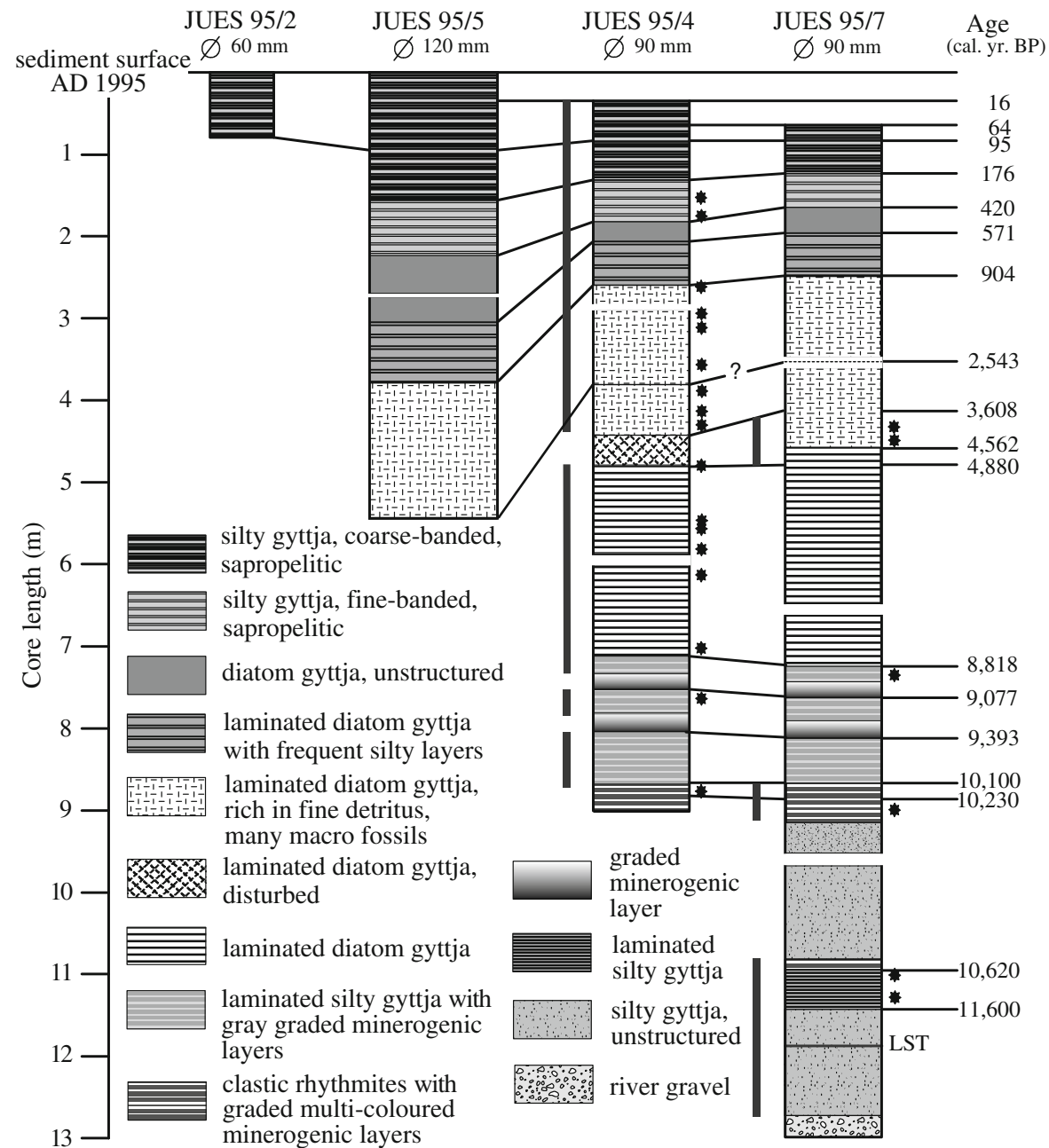

Table 2 Location of thin sections in core JUES 95/7

\begin{tabular}{lccc}
\hline Thin section (no.) & Sediment depth $(\mathrm{cm})$ & Age $($ cal. yr. BP) & Pollen zone \\
\hline 1 & $995.5-985.5$ & $10,630-10,560$ & Va \\
2 & $824-813.3$ & $10,400-10,340$ & Va \\
3 & $692-682$ & $9,245-9,120$ & Vb/VI \\
4 & $641-631$ & $8,920-8,690$ & VI \\
5 & $535-525$ & $7,430-6,880$ & VI \\
6 & $409-399$ & $4,910-4,760$ & VIIIa \\
7 & $241-231$ & $1,630-1,490$ & IX \\
\hline
\end{tabular}

Pollen analysis

Pollen samples $\left(0.6-2 \mathrm{~cm}^{3}\right.$ of sediment) were treated with hot potassium hydroxide $(\mathrm{KOH})$, with hydrochloric and hydrofluoric acids $(\mathrm{HCl}$ and $\mathrm{HF}$, respectively), then acetolysed (Beug 1957) and sieved in a water bath (ultrasonic sieving) to remove particles $<10 \mu \mathrm{m}$.

A minimum of 1,000 arboreal pollen grains, excluding Corylus, was counted in each of close to 300 samples, except for a few late-glacial samples, which were very poor in pollen. The mean 


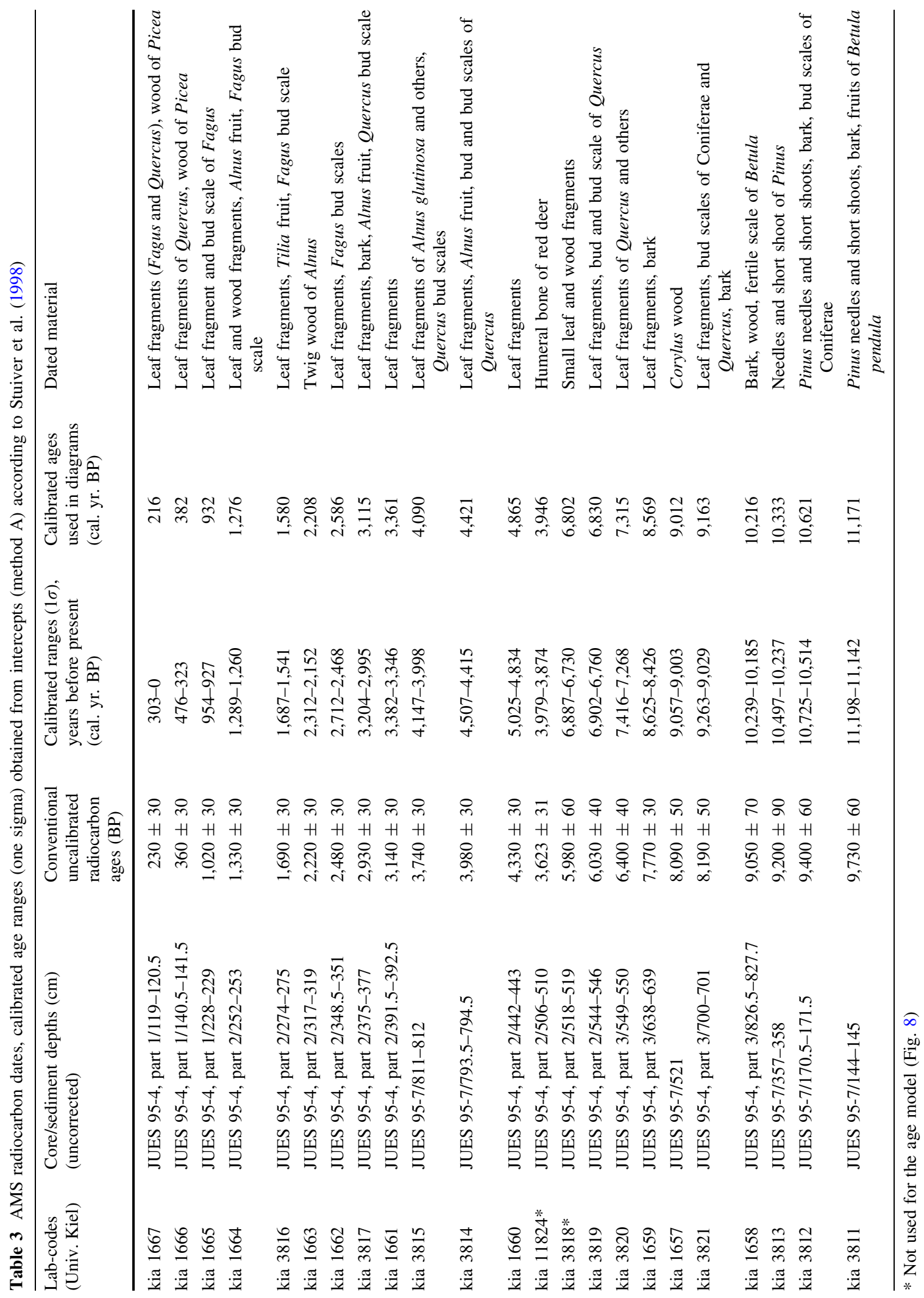




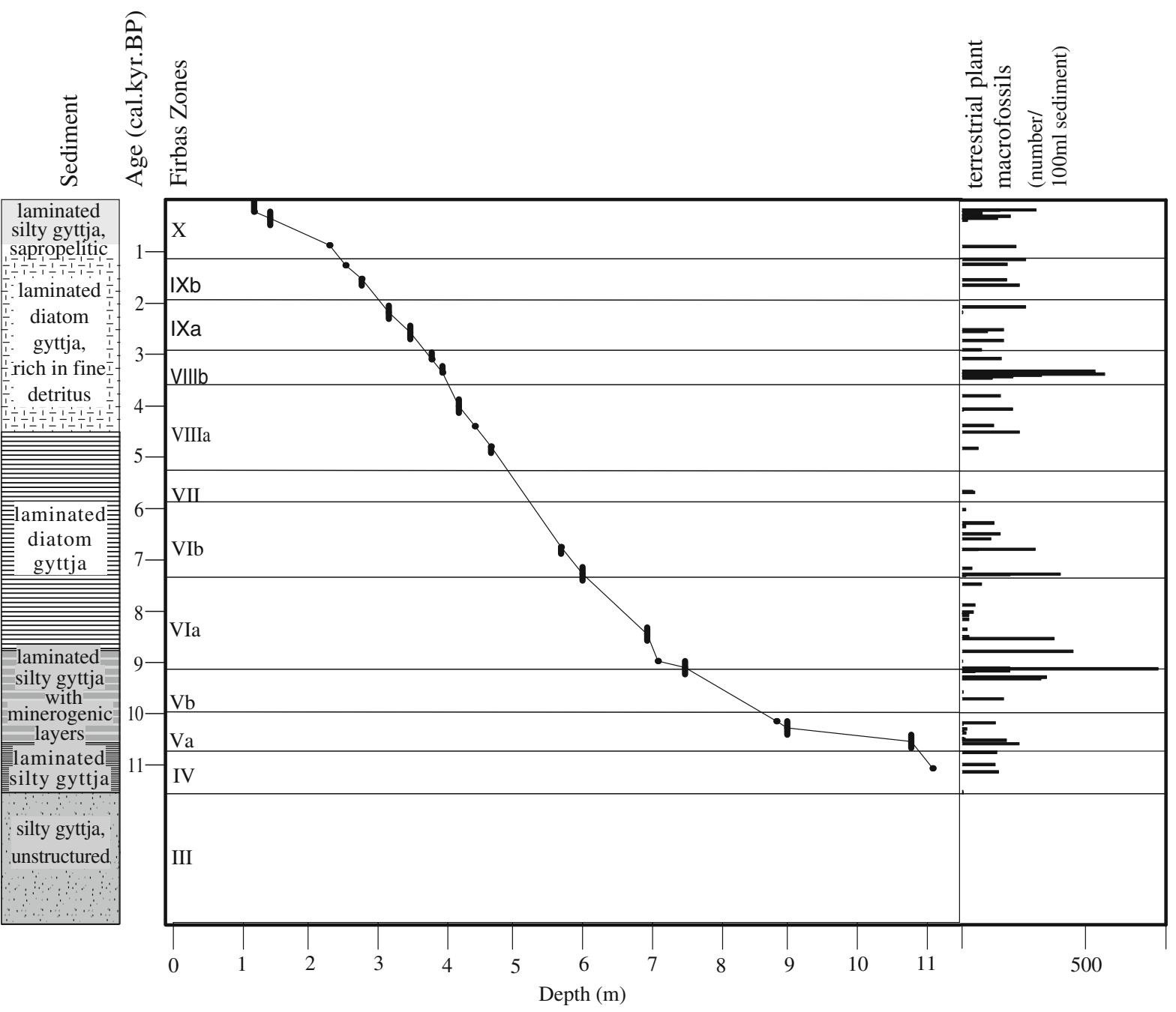

Fig. 8 AMS radiocarbon dates (with standard deviation) versus sediment depth. Additonally, sediment stratigraphy, Firbas zones and terrestrial macrofossil abundances are shown.

temporal resolution is 32 calendric years for phases of human settlement and 47 years for the entire sequence.

In addition to a reference pollen collection, pollen keys were used to determine unknown pollen grains and spores (Beug 1961; Fægri et al. 1989; Moore et al. 1991). Remains of green algae were determined using Komárek and Fott (1983). The pollen diagram (Fig. 9) is subdivided into pollen zones according to Firbas (1949, 1952), Beug (1992), Bartens (1990), and Chen (1982). The criteria on which the zonation is based are listed in Table 4. The pollen content of the minerogenic layers is shown in Table 9. The
Note two apparently false AMS-dates were not used for the Age-Depth-Model (for discussion see text)

counts are accessible via the Pangaea database (http://www.pangaea.de/PangaVista).

\section{Macrofossils}

The samples for macrofossil analysis were wet-sieved (mesh size $0.3 \mathrm{~mm}$ ) and then analysed under a stereomicroscope and an additional transmissionlight-microscope for high enlargements. Seeds and bud scales were determined by use of reference collections. Leaves were determined by the characteristic epidermal cell pattern. The identification key of Haas (1994) was used for charophyte oospores. 


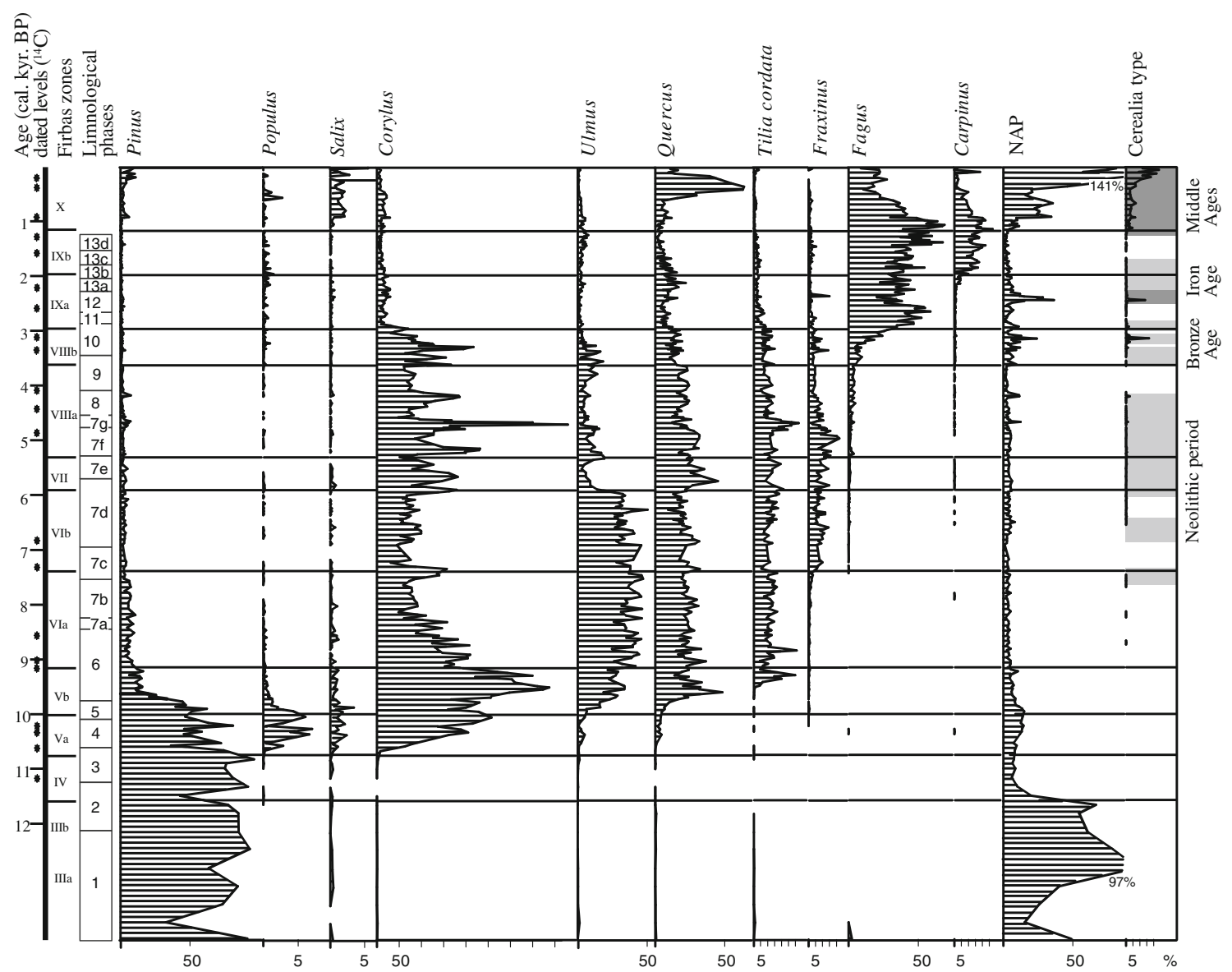

Fig. 9 Frequency diagram of significant pollen types. Percentages are based on the sum of arboreal pollen types (AP) excluding Corylus. Zonation according to Firbas $(1949,1952)$.
Human settlement phases are indicated by different grey shades according to their intensity (darker grey $=$ more intensive land use)

Table 4 Criteria for zonation of the Lake Jues pollen stratigraphy according to Firbas (1949, 1952), Beug (1992), Bartens (1990) and Chen (1982), and ages of zone boundaries (cal. yr. BP) at Lake Jues

\begin{tabular}{llll}
\hline Firbas pollen zones (biozones) & & Age & Criteria for zonation \\
\hline Older Subatlantic, part b/Younger Subatlantic & IXb/X & 1,160 & Cerealia $>1 \%$ \\
Older Subatlantic, part a/part b & IXa/IXb & 1,970 & Carpinus $>5 \%$ \\
Younger Subboreal/Older Subatlantic & VIIIb/IXa & 2,960 & Fagus becomes dominant \\
Older Subboreal/Younger Subboreal & VIIIa/VIIIb & 3,620 & Fagus $>5 \%$ \\
Younger Atlantic/Older Subboreal & VII/VIIIa & 5,300 & Fagus $>1 \%$ \\
Older Atlantic/Younger Atlantic & VIb/VII & 5,910 & Ulmus percentages decrease (elm decline) \\
Older Atlantic, part a/part b & VIa/VIb & 7,390 & Fraxinus percentages increase, first Fagus pollen grain \\
Younger Boreal/Older Atlantic & Vb/VIa & 9,160 & Pinus $<10 \%$ \\
Older Boreal/Younger Boreal & Va/Vb & 10,020 & Quercus, Ulmus, Tilia, Fraxinus $>10 \%$ \\
Preboreal/Older Boreal & IV/Va & 10,770 & Corylus $>5 \%$ \\
Younger Dryas/Preboreal & III/IV & 11,600 & NAP percentages decrease \\
\hline
\end{tabular}


Diatom analysis and thin sections

Wet sediment samples of ca. $0.5 \mathrm{ml}$, were treated with hot hydrogen peroxide (30\%) for at least $24 \mathrm{~h}$. After complete evaporation the samples were re-suspended in water and conserved with formaldehyde for storage. Diluted subsamples of $10 \mu \mathrm{l}$ volumes were mounted in Naphrax ${ }^{\circledR}$. All diatom valves and chrysophyte cysts in this $10-\mu 1$ drop or of an aliquot were identified and counted. Valve concentrations were calculated following the aliquot method by Battarbee (1986). Mean diatom concentrations as high as $470,000,000$ valves $/ \mathrm{cm}^{3}$ sediment required several dilution steps. As the error increases with dilution, this method yields rough estimates only (Wolfe 1997). The diatom influx (valves $\times \mathrm{cm}^{-2} \times \mathrm{a}^{-1}$ ) was calculated using concentration and sedimentation rates.

Altogether, 178 diatom samples were counted and taxonomically analysed. The mean temporal resolution is 100 years. A minimum of 1,000 valves, on average 2,700 valves per sample, were counted using a Leica DMLS microscope with oil immersion and phase contrast at $1,000 \times$ magnification. The taxonomy follows Krammer and Lange-Bertalot (19861991). In addition the following publications were used for identification: Reichardt and Lange-Bertalot (1991) for Gomphonema, Witkowski et al. (1995/96) for Fragilaria martyi, Lange-Bertalot and Moser (1994) for the genus Brachysira, Lange-Bertalot (1993) and Lange-Bertalot and Metzeltin (1996) for several Navicula and Gomphonema species. New genus names such as Sellaphora are used for newly described species only, not for renamed ones. This allows easier access to published ecological information. C. pseudocomensis according to Scheffler (1994) and Cyclotella comensis were not differentiated, because the intraspecific variation seems to be too large and overlapping.

The results of the diatom analysis, calculated as percents $(100 \%=$ sum of counted valves), total concentration, and total influx, are shown in Figs. 10 and 11 and Table 9. The counts are available in the database PANGAEA (http://www.pangaea.de/ PangaVista). The diatom diagram is subdivided into Firbas pollen zones and limnological phases (Table 8).

Thin sections for annual and subannual varve analysis were prepared according to Merkt (1971) and microscopically examined at $250 \times, 400 \times$ and $1,000 \times$ magnification with linear and crossed polarised light. Annual lamination is documented by photography in Baier (1997).

Numerical reconstruction of trophic status

The distribution of diatom species is highly controlled by total phosphorus (TP) concentrations (Hofmann 1994; Kelly and Whitton 1995; Lotter et al. 1998; Wunsam et al. 1995). Trophic preference and tolerance of a species can be calculated from its relative frequencies and the accompanying measured TPconcentrations by using the methods of weighted averaging (ter Braak and van Dam 1989; ter Braak and Juggins 1993). However, preference and tolerance can also be determined empirically from the frequency distribution along a TP-gradient by assigning the species to defined trophic classes (Hofmann 1994). For both methods TP-concentrations should cover a wide range and should be distributed as evenly as possible along the gradient. Based on optima and tolerances, TP-concentrations or trophic conditions during past time periods can be reconstructed using diatom assemblages in a sediment core.

In this study we performed a TP-reconstruction (Fig. 11) using the method described by Hofmann (1994, also compare Kelly and Whitton 1995) in combination with ecological information from the TPdata sets of the European Diatom Database (EDDI, Bennion et al. 1996; Lotter et al. 1998; Rioual 2000), excluding the Central European data set CEURO (Wunsam and Schmidt 1995). CEURO was not used, because here Stephanodiscus minutulus was not always distinguished from S. alpinus. In contrast to Kelly and Whitton (1995), who worked on rivers with a very wide TP-range, Hofmann investigated periphyton communities of 44 circumneutral and alkaline lakes in Southern and Western Germany (TP-gradient from 6 to $64 \mu \mathrm{g} / \mathrm{l})$. Based on these TP-concentrations and on published information, Hofmann assigned a trophic status to every lake following Vollenweider (1979). She distinguished five groups of lakes: oligotrophic $=1$, oligo-/mesotrophic $=2$, mesotrophic $=3$, meso- to eutrophic $=4$ and eutrophic $=5$. Hofmann then calculated the trophic state value of the species by weighted averaging (Zelinka and Marvan 1961; ter Braak and van Dam 1989), using the figure of the trophic status as the variable. In a second step, the trophic state tolerances of every species were empirically determined from their distribution along 
Table 5 Characterization of the diatom tolerance groups according to Hofmann (1994)

\begin{tabular}{llll}
\hline Tolerance group & Weighting & Milieu of occurrence & $\begin{array}{l}\text { TP-conc. }(\mu \mathrm{g} / \mathrm{l}) \text { acc. to } \\
\text { Vollenweider }(1979)\end{array}$ \\
\hline Oligotrophic species & 3 & Restricted to oligotrophic & $<11.8$ \\
Oligo- $\beta$-mesotrophic species & 2 & From oligotrophic to moderately mesotrophic & $<19$ \\
Oligo- $\alpha$-mesotrophic species & 1 & From oligotrophic to strongly mesotrophic, & $<26.8$ \\
& & not tolerating eutrophic conditions & $\geq 26.8$ \\
$\alpha$-Meso-eutrophic species & 2 & From moderately mesotrophic to eutrophic & $>46.5$ \\
Eutrophic species & 3 & Restricted to eutrophic & \\
Tolerant species & 0 & No clear relation to trophic status discernible & \\
\hline
\end{tabular}

the TP-gradient. Six tolerance groups were distinguished according to the criteria listed in Table 5. The tolerance groups are overlapping and limited on one side only, because the frequencies of most species are not symmetrically distributed along the TP-gradient. Weightings depend upon the tolerance ranges (stenoecious $=3$, euryoecious $=0$ ). This classification of species was then scrutinized and in some cases corrected by comparison with diatom assemblages from 155 additional European lakes (slides from Coll. Lange-Bertalot) and published information. Hofmann's classification was confirmed by experiments (Reimann 1998).

Using these autecological data, the unknown trophic status of a lake can be inferred by weighted averaging, using the species' abundances, trophic state values and weightings:

$T I=\frac{\sum_{i=1}^{n} H_{i} \times G_{i} \times T_{i}}{\sum_{i=1}^{n} H_{i} \times G_{i}}$

$T I=$ trophic state index, $H_{\mathrm{i}}=$ relative abundance of species $\mathrm{i}, G_{\mathrm{i}}=$ weighting of species $i, T_{\mathrm{i}}=$ trophic state value of species $i$.

Table 6 shows the relation between trophic state index $T I$ and trophic status. This method was successfully used in many lake monitoring programs

Table 6 Relation between trophic state index and trophic status, according to Hofmann (1994)

\begin{tabular}{ll}
\hline Trophic state index & Trophic status \\
\hline $1.00-1.99$ & Oligotrophic \\
$2.00-2.49$ & Oligo- to mesotrophic \\
$2.50-3.49$ & Mesotrophic \\
$3.50-3.99$ & Meso- to eutrophic \\
$4.00-5.00$ & Eutrophic \\
\hline
\end{tabular}

on Bavarian lakes (Hofmann, 1999; Hofmann and Schaumburg 2005a-d).

To date, this data set comprises 448 species and their trophic state classification (Hofmann 1999). In the fossil samples of Lake Jues, 439 diatom taxa were identified (71 species per sample on average). Thereof, 160 taxa are not classified by Hofmann, but comprise the most dominant planktonic species. Trophic state values of these species were estimated by their distribution in the combined TP-data set from EDDI, but also by compiling published references (Table 7). 77 species remained unclassified, of those only three constitute more than $1 \%$ in the Lake Jues profile (Fragilaria capucina Desmazières 1925, F. pseudoconstruens Marciniak 1982 and F. microstriata Marciniak 1982).

A diversity of indicator species is required to make accurate paleoenvironmental inferences. Hofmann (1994, 1999) recommends that at least 10 indicator species per sample should be present, which do not necessarily have to occur at high abundances. Good indicator taxa often are quite rare, while tolerant species can be very abundant. Amongst the latter are many small opportunistic taxa with fast reproduction and immigration rates, e.g. Achnanthes minutissima Kützing 1833 and Fragilaria construens (Ehrenberg) Grunow 1862. The mean number of indicator species is 31 , with abundances between 1.7 and $96 \%$ (59\% on average). Only one of the samples contains less than 10 indicator species.

\section{Results and discussion}

Lithology and laminations

The predominant sediments of Lake Jues are annually laminated silty gyttjas with changing proportions of 
fine and coarse detritus (Fig. 7). The laminations show characteristic patterns allowing a precise correlation of the cores. Several macroscopic and microscopic features of the record provide evidence of the limnological conditions during the time of deposition.

\section{Lamination}

Dark and light laminae, 0.04-1.4 mm thick, alternate in the record. During spring and summer, a sequence of algae blooms, mainly diatoms, but also cysts of Chrysophyceae, contribute to one or a few light sublaminae. Pollen grains of Corylus, Alnus, Betula, Quercus and Pinus in the light layers indicate spring and early summer as the time of deposition. The dark layers, consisting mainly of inorganic and organic fine detritus, i.e. material derived from the lake's littoral and the catchment area, represent fall and winter. Planktonic diatoms are usually rare in the dark layers because of the low phytoplankton production during winter (Baier 1997).

Annual laminations are mainly preserved in small (surface $<100$ ha) and deep lake basins. This topography favours anoxic conditions in the hypolimnion depending upon circulation pattern, length of stagnation periods, and the amount of organic production. Lasting stagnation results in accumulation of organic matter at more or less reducing conditions in the hypolimnion and, at the same time, nutrient depletion in the epilimnion. High concentrations of dissolved and suspended substances in the hypolimnion can prevent deep mixing and thus cause biogenic meromixis (Sommer 1994). Meromixis is also favoured by a more continental climate with stable winter and summer weather and short transitional seasons.

\section{Sediment colours}

Before 8,300 cal. yr. BP and after 2,500 cal. yr. BP, the sediments in Lake Jues are mainly grey or greenish. The long section in between is nearly exclusively black (Fig. 11). Reddish colours, due to the $\mathrm{Fe}^{3+}$ minerals hematite and goethite, occur in minerogenic layers between 10,620 and 10,100 cal. yr. BP and between 4,300 and 3,440 cal. yr. BP. Fe-Oxides are only preserved under oxic conditions in the hypolimnion and at low organic production. With increasing temperature and organic production, Fe-oxides are reduced during the diagenesis of the sediments resulting in first greenish and, finally, grey and black sediments (Hinze and Meischner, 1968). The black stain indicates reduction of sulphate and formation of iron sulphides in the pore waters or, in extreme cases, already above the sediment surface. The grade of reduction of iron may be taken as an indication of increased organic production and reduced circulation, a trend generally favoured by rising temperatures in a temperate climate. However, a direct reference to seasonal circulation patterns is not possible.

\section{Vivianite}

Bright-blue clusters of vivianite crystals $\left(\mathrm{Fe}_{3}\left(\mathrm{PO}_{4}\right)_{2}\right.$. $8 \mathrm{H}_{2} \mathrm{O}$ ) occur at the base of the limnic sediments, and become frequent with the increasing burial of undecomposed organics, finally forming nodules and crusts parallel to the bedding. The precipitation of vivianite clearly precedes the formation of sulphides in the course of eutrophication (Gächter and Müller 2003). In Lake Jues, vivianite formation ceased about 9,900 cal. yr. BP, and was replaced by black sulphides (Fig. 11).

Orthophosphate is provided by the oxic decay of organics while the iron is delivered as $\mathrm{Fe}^{2+}$-ions from already reduced sediments. Thus vivianite forms at a high redox-gradient close to or at the sediment surface, and at high phosphate concentrations and availability of reduced pore fluids, most likely due to expulsion of pore water by compaction of the deeper sediment. Oxic decay in the hypolimnion is indicated by complete dissolution of carbonate by the resulting $\mathrm{CO}_{2}$ (Emerson and Bender 1981). Phosphorus may also be provided by carbonate dissolution as carbonate lattices can contain up to $600 \mathrm{ppm}$ phosphorus (Morse and Mackenzie 1990).

Vivianite therefore is an indicator of at least temporary deep circulation at high organic production. The accumulation of massive vivianite may have prevented the cycling of phosphorus and, hence, hampered the establishment of a rich trophic system during the early stages of Lake Jues.

Diatom stratigraphy and ecology

The stratigraphy of the common diatoms is shown in Figs. 10 and 11 and in Table 8 . Their trophic state values, used for the diatom-inferred trophic state index, are given in Table 7. 
Table 7 Trophic state values of frequent planktonic species of ancient Lake Jues

\begin{tabular}{|c|c|c|c|}
\hline Species & $\begin{array}{l}\text { Trophic } \\
\text { state value }\end{array}$ & Weighting & Reference \\
\hline Asterionella formosa Hasall 1850 & 4 & 1 & $\begin{array}{l}\text { EDDI TP-data sets, van Dam } \\
\text { et al. (1994), Denys (1991) }\end{array}$ \\
\hline Aulacoseira granulata (Ehrenberg) Simonsen 1979 & 4 & 2 & $\begin{array}{l}\text { EDDI TP-data sets, Whitmore } \\
\text { (1989) }\end{array}$ \\
\hline $\begin{array}{l}\text { Cyclotella comensis/pseudocomensis (Cyclotella comensis Grunow } \\
\text { in Van Heurck 1882, Cyclotella pseudocomensis Scheffler 1994) }\end{array}$ & 2.5 & 1 & EDDI TP-data sets \\
\hline Cyclotella ocellata Pantocsek 1901 & Tol & 0 & EDDI TP-data sets \\
\hline Cyclotella radiosa (Grunow) Lemmermann 1900 & 2.5 & 1 & EDDI TP-data sets \\
\hline Fragilaria crotonensis Kitton 1869 & Tol & 0 & $\begin{array}{l}\text { EDDI TP-data sets, Hofmann } \\
\text { (1999) }\end{array}$ \\
\hline Fragilaria capucina var. gracilis (Oestrup) Hustedt 1950 & Tol & 0 & Hofmann (1999) \\
\hline Fragilaria delicatissima (W. Smith) Lange-Bertalot 1980 & 2 & 2 & Hofmann (1999) \\
\hline Fragilaria tenera (W. Smith) Lange-Bertalot 1980 & 2.5 & 1 & Hofmann (1999) \\
\hline Nitzschia paleacea (Grunow) Grunow in Van Heurck 1881 & 5 & 3 & $\begin{array}{l}\text { Hofmann (1999), van Dam et al. } \\
\text { (1994) }\end{array}$ \\
\hline Stephanodiscus alpinus Hustedt in Huber-Pestalozzi 1942 & Tol & 0 & $\begin{array}{l}\text { Stoermer }(1984,1993), \text { Hickel } \\
\text { and Håkansson (1993) }\end{array}$ \\
\hline $\begin{array}{l}\text { Stephanodiscus parvus/minutulus (S. parvus Stoermer and Håkansson } \\
\text { 1984, S. minutulus (Kützing) Cleve and Möller 1878) }\end{array}$ & 4.3 & 2 & EDDI TP-data sets \\
\hline
\end{tabular}

Asterionella formosa is the most abundant species of the record, only becoming rare between 12,000 and 11,000 cal. yr. BP, 4,000 and 2,900 cal. yr. BP and between 2,600 and 2,000 cal. yr. BP. While some authors describe Asterionella formosa as tolerant (Round 1981; Round and Brook 1959; Bradbury 1975; Dixit and Dickman 1986), the EDDI TP-data sets clearly show its meso- to eutrophic distribution, and thereby confirms the classification of van Dam et al. (1994) and Denys (1991). Cyclotella comensis, frequent in Lake Jues throughout the Holocene except for parts of the Atlantic period and the last 2,000 years, usually occurs at oligotrophic to $\alpha$-mesotrophic conditions (Hofmann 1994, 1999; TP-data sets of EDDI). This agrees with observations that show increasing abundances of $C$. comensis following a modest nutrient enrichment (Fritz et al. 1993; Stoermer 1993). Cyclotella ocellata mainly occurred during the Atlantic and between 2,000 and 1,000 cal. yr. BP. The species is classified as oligotraphentic (Stoermer and Yang 1970; Denys 1991) as well as meso- to eutraphentic (van Dam et al. 1994). According to the combined TP-data set, this species is not indicative of lower trophic state conditions, although it shows decreasing vitality at TP-concentrations $>100 \mu \mathrm{g} / \mathrm{l}$. For Fragilaria crotonensis, found in Lake Jues during the Subatlantic, the combined TP-data set shows no clear relation to TP-concentrations and confirms the estimate of Hofmann (1994, 1999). Nitzschia paleacea, common in Lake Jues only during the Older Subatlantic, is an eutraphentic species (Hofmann 1994, 1999), that additionally indicates high $\mathrm{NH}_{4}$-concentrations (Hürlimann and Schanz 1993) and becomes more abundant with increasing organic pollution ( $\alpha$-mesosaprobic, Krammer and Lange-Bertalot 1986-1991). Stephanodiscus alpinus occurred nearly exclusively during the Preboreal and Boreal. The species seems to be distributed in oligo- to mesotraphentic conditions according to the combined TP-data. However, other studies describe its morphological adaptations to changing nutrient concentrations and classify the species as tolerant (Stoermer 1984, 1993; Hickel and Håkansson 1993). The high P-requirement of Stephanodiscus parvus/minutulus is well-known (e.g. van Dam et al. 1994; Kilham et al. 1986), its vitality under mesotrophic conditions, however, is only shown by the EDDI TP-data set (excluding the 
CEURO data set). Hence, this species has similar P-demands as Asterionella formosa, but was not as abundant in Lake Jues as the latter.

In addition to phosphorus, silicon is important for growth and vitality of diatoms with Si:P-ratios as a factor for dominance and seasonal succession of the planktonic species. Several diatom species prefer specific Si:P-ratios. According to Kilham et al. (1986), Sommer (1987) and Tilman et al. (1982), Fragilaria and Asterionella and probably also the needlelike Nitzschia spp. are good competitors for $\mathrm{P}$ and relatively poor competitors for $\mathrm{Si}$ and hence prefer high Si:P-ratios. Fragilaria delicatissima is even more Si-demanding than Asterionella. In contrast Stephanodiscus minutulus has high demands for $\mathrm{P}$, but only low Si-requirements. Cyclotella comensis and Cyclotella radiosa grow well at low $\mathrm{Si}$ - and P-concentrations (Raeder 1990; Wolin et al. 1988). The changing dominance of species with different $\mathrm{Si}$ and P-preferences can be shown more clearly by assigning the long Fragilaria spp. and Asterionella to a high Si:P-ratio taxon group. Stephanodiscus minutulus represents the low Si:P-ratio group.

Limnological reconstructions through time

(Figs. 10 and 11, Table 8)

\section{Younger Dryas (pollen zone III)}

The limnic sediments are underlain by strongly weathered gravel. After the formation of the sinkhole lake, $124 \mathrm{~cm}$ of unstructured silty gyttja with sand and gravel layers and vivianite concretions were deposited upon the gravel.

Low pollen concentrations combined with high percentages of nonarboreal pollen (NAP), Pinus and Betula allow us to conclude that the oldest lake sediments date from the Younger Dryas at least. The sand and gravel layers, numerous reworked pollen grains, pre-Quaternary sporomorphs, and rheophilous and aerophilous diatoms, such as Meridion circulare (Greville) C.A. Agardh 1831, Diatoma mesodon (Ehrenberg) Kützing 1844, Fragilaria arcus (Ehrenberg) Cleve 1898, Navicula gallica var. perpusilla (Grunow) Lange-Bertalot 1985, N. contenta Grunow in Van Heurck 1880, and Pinnularia borealis Ehrenberg 1843, indicate strong erosive processes (pollen zone IIIa). The terrestrial plant cover was apparently fragmentary, but became gradually denser so that the inflow of minerogenic detritus decreased (pollen zone IIIb).

Limnological phase 1 (Table 8): The aquatic and telmatic vegetation of Lake Jues was still rather sparse at this time. Typha latifolia type, Typha angustifolia type, and Potamogeton (proved by a few pollen grains) as well as algae, mainly diatoms and Chrysophyceae, were present (Figs. 10, 11). Diatom concentrations were relatively low (mean $13 \times 10^{7}$ valves $/ \mathrm{cm}^{3}$ ). The high percentages of planktonic diatoms show that not only pollen of thermophilous species from older interglacials, but also an unknown quantity of diatom valves were redeposited during the time of zone IIIa.

Limnological phase 2: Starting with pollen zone IIIb, the diatom associations reflect ecological conditions no longer influenced by redeposition. At that time Lake Jues was mesotrophic (Fig. 11). The absence of varves and the occurrence of vivianite concretions indicate holomixis which must have occurred during the short ice-free periods (cold monomictic).

Simultaneously with reduced terrigenous inflow, the portions of the planktonic diatom species (mainly Asterionella formosa and Cyclotella comensis) decreased from $30 \%$ to $10 \%$, while diatom concentrations increased (mean $20 \times 10^{7}$ valves $/ \mathrm{cm}^{3}$ ). Small, probably tychoplanktonic Fragilaria spp. and periphytic species dominated the diatom assemblages, a phenomenon typical of the late glacial and the early Post-glacial, and a characteristic of modern Arctic lakes (Haworth 1976; Lotter and Bigler 2000; Marciniak 1986; Smol 1983, 1988). Diatom plankton bloomed during the short ice-free periods. In the littoral zone, where the ice disappeared earlier in the year, a pioneer association of periphytic and tychoplanktonic diatoms (mainly Fragilaria robusta (Fusey) Manguin and F. martyi (Heribaud) LangeBertalot 1993) developed (Lotter and Bigler 2000; Smol 1983, 1988). Species which are now common in the cold nordic-alpine, arctic-boreal, and alpine regions (Krammer and Lange-Bertalot 1986-1991) were part of these assemblages ("cold water diatoms"): Achnanthes bioretii Germain 1957, A. flexella (Kützing) Brun 1880, A. gracillima Hustedt 1927, A. laevis Oestrup, A. levanderi Hustedt 1933, Amphora fogediana Krammer 1985, Cymbella reichardtii Krammer 1985, Gomphonema ventricosum Gregory 1856, and Nitzschia alpina Hustedt 1943 emend. Lange-Bertalot 1980 (Fig. 11). These species 
Table 8 Characterization of limnological phases in Lake Jues

\begin{tabular}{|c|c|c|c|}
\hline $\begin{array}{l}\text { Limnolog. } \\
\text { phases }\end{array}$ & Age & Characteristic features & Circulation \\
\hline 1 & & Redeposited diatoms abundant, "cold-water diatoms" present & Monomictic \\
\hline 2 & & $\begin{array}{l}\text { Small Fragilaria spp. and periphytic species dominant, "cold-water } \\
\text { diatoms" decreasing, Stephanodiscus alpinus present }\end{array}$ & Monomictic \\
\hline 3 & $11,200-10,620$ & $\begin{array}{l}\text { Increase of planktonic species (Cyclotella comensis/pseudocomensis, } \\
\text { Asterionella formosa, Stephanodiscus minutulus), Stephanodiscus } \\
\text { alpinus common }\end{array}$ & Dimictic \\
\hline 4 & $10,620-10,100$ & $\begin{array}{l}\text { Dominance of small Fragilaria spp. and periphytic species, } \\
\text { "cold-water diatoms" more frequent again, sedimentation } \\
\text { of clastic rhythmites }\end{array}$ & Dimictic \\
\hline 5 & $10,100-9,500$ & $\begin{array}{l}\text { Dominance of planktonic species (Cyclotella comensis/ } \\
\text { pseudocomensis, Asterionella formosa, Stephanodiscus } \\
\text { minutulus), "cold-water diatoms", and Stephanodiscus } \\
\text { alpinus still present }\end{array}$ & $\begin{array}{l}\text { Alternating holo- } \\
\text { and meromictic }\end{array}$ \\
\hline 6 & $9,500-8,400$ & $\begin{array}{l}\text { Disappearance of "cold-water diatoms" and Stephanodiscus } \\
\text { alpinus, planktonic diatom assemblages more diverse }\end{array}$ & $\begin{array}{l}\text { Alternating holo- } \\
\text { and meromictic }\end{array}$ \\
\hline 7 & $8,400-4,550$ & Coccal green algae (Botryococcus, Tetraedron) abundant & Meromictic \\
\hline a & $8,400-8,200$ & Increase of coccal green algae & Meromictic \\
\hline $\mathrm{b}$ & $8,200-7,530$ & High abundance of Asterionella formosa & Meromictic \\
\hline $\mathrm{c}$ & $7,530-6,750$ & Dominance of Cyclotella spp. & Meromictic \\
\hline d & $6,750-5,700$ & $\begin{array}{l}\text { Dominance of Cyclotella spp. continues, higher values } \\
\text { of Myriophyllum spicatum pollen grains as well as } \\
\text { of tychoplanktonic and periphytic diatoms, low } \\
\text { diatom influx }\end{array}$ & Oligomictic \\
\hline e & $5,700-5,250$ & $\begin{array}{l}\text { Low values of coccal green algae and Myriophyllum spicatum, } \\
\text { high percentages of Stephanodiscus minutulus and } \\
\text { Cyclotella radiosa }\end{array}$ & Oligomictic \\
\hline $\mathrm{f}$ & $5,250-4,770$ & $\begin{array}{l}\text { High abundances of coccal green algae, more diverse } \\
\text { diatom assemblages, high pollen values of Myriophyllum } \\
\text { spicatum }\end{array}$ & $\begin{array}{l}\text { Meromictic and } \\
\text { oligomictic }\end{array}$ \\
\hline $\mathrm{g}$ & $4,770-4,550$ & $\begin{array}{l}\text { Still higher abundances of coccal green algae, decreasing values } \\
\text { of Myriophyllum spicatum, Cyclotella radiosa and Asterionella } \\
\text { formosa dominant }\end{array}$ & Meromictic \\
\hline 8 & $4,550-4,100$ & $\begin{array}{l}\text { Asterionella formosa dominant, decreasing values of coccal } \\
\text { green algae }\end{array}$ & Oligomictic \\
\hline 9 & $4,100-3,450$ & $\begin{array}{l}\text { Fragilaria capucina var. gracilis, F. delicatissima and Cyclotella } \\
\text { spp. dominant, reddish sediment colours }\end{array}$ & $\begin{array}{l}\text { Holomictic phases more } \\
\text { frequent }\end{array}$ \\
\hline 10 & $3,450-2,850$ & Cyclotella spp. dominant, Characeae present & Oligo- or meromictic \\
\hline 11 & $2,850-2,650$ & $\begin{array}{l}\text { Asterionella formosa, Fragilaria capucina var. gracilis, } \\
\text { and } F \text {. delicatissima dominant }\end{array}$ & Oligomictic \\
\hline 12 & $2,650-2,280$ & $\begin{array}{l}\text { Settlement phase (Iron Age), alternating dominances } \\
\text { of Stephanodiscus minutulus, Cyclotella comensis/ } \\
\text { pseodocomensis and Nitzschia paleacea }\end{array}$ & $\begin{array}{l}\text { Oligomictic and } \\
\text { dimictic }\end{array}$ \\
\hline 13 & $2,280-1,240$ & $\begin{array}{l}\text { Asterionella formosa, Fragilaria capucina var. gracilis, } \\
\text { and } F \text {. delicatissima abundant }\end{array}$ & Dimictic \\
\hline a & $2,280-2,050$ & Si-preferring diatoms dominant, reddish sediment colours & Dimictic \\
\hline $\mathrm{b}$ & $2,050-1,800$ & Cyclotella ocellata dominant, Si-preferring diatoms subdominant & Dimictic \\
\hline $\mathrm{c}$ & $1,800-1,500$ & Si-preferring diatoms dominant & Dimictic \\
\hline $\mathrm{d}$ & $1,500-1,240$ & Cyclotella spp. dominant, Si-preferring diatoms subdominant & Dimictic \\
\hline
\end{tabular}




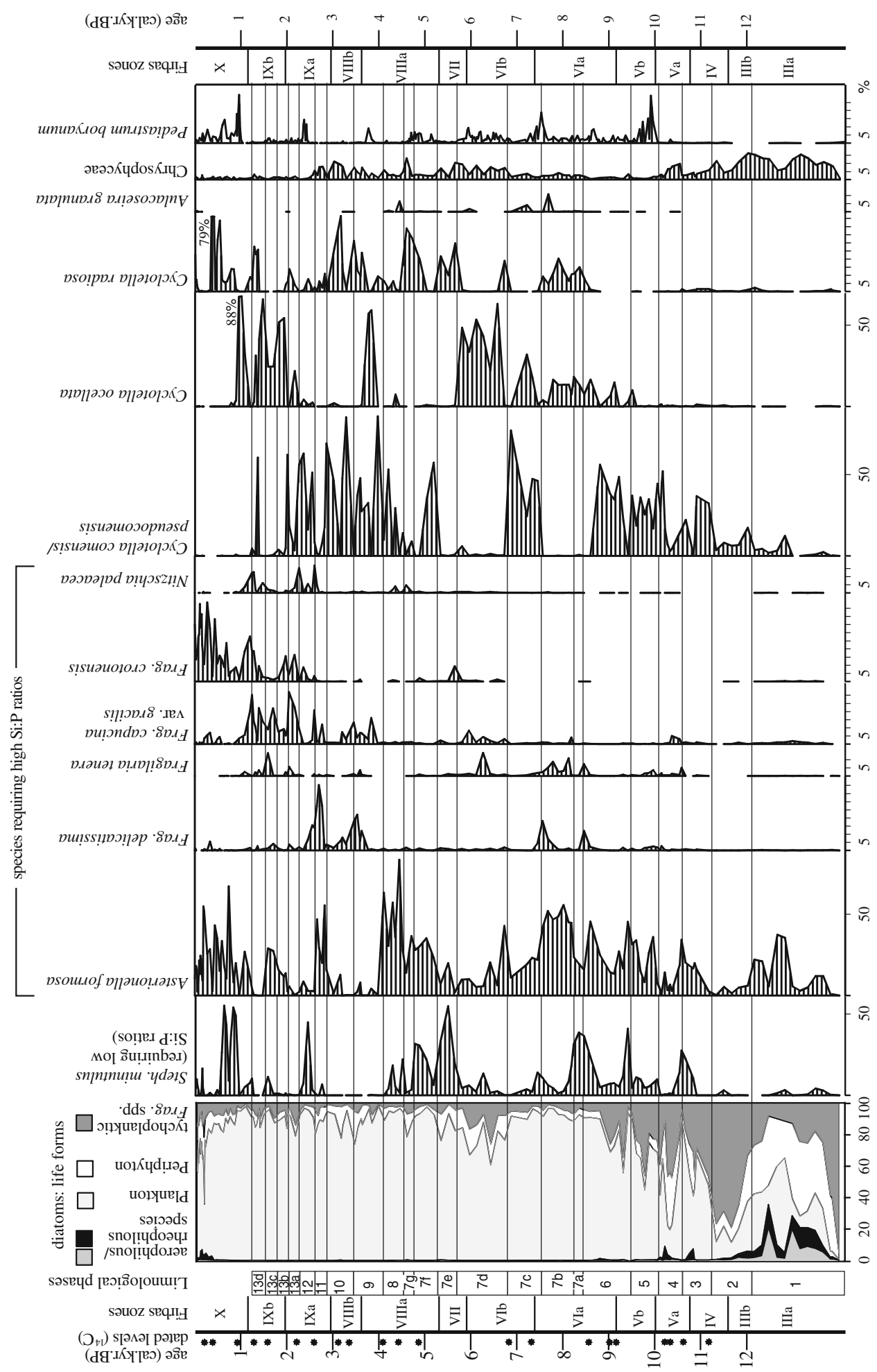

Fig. 10 Percentage diagram of diatom life forms and of the most important planktonic diatoms, chrysophyte cysts and Pediastrum boryanum. Percentages are based on the total of diatom valves or the tree pollen sum (in the case of Pediastrum boryanum), respectively 


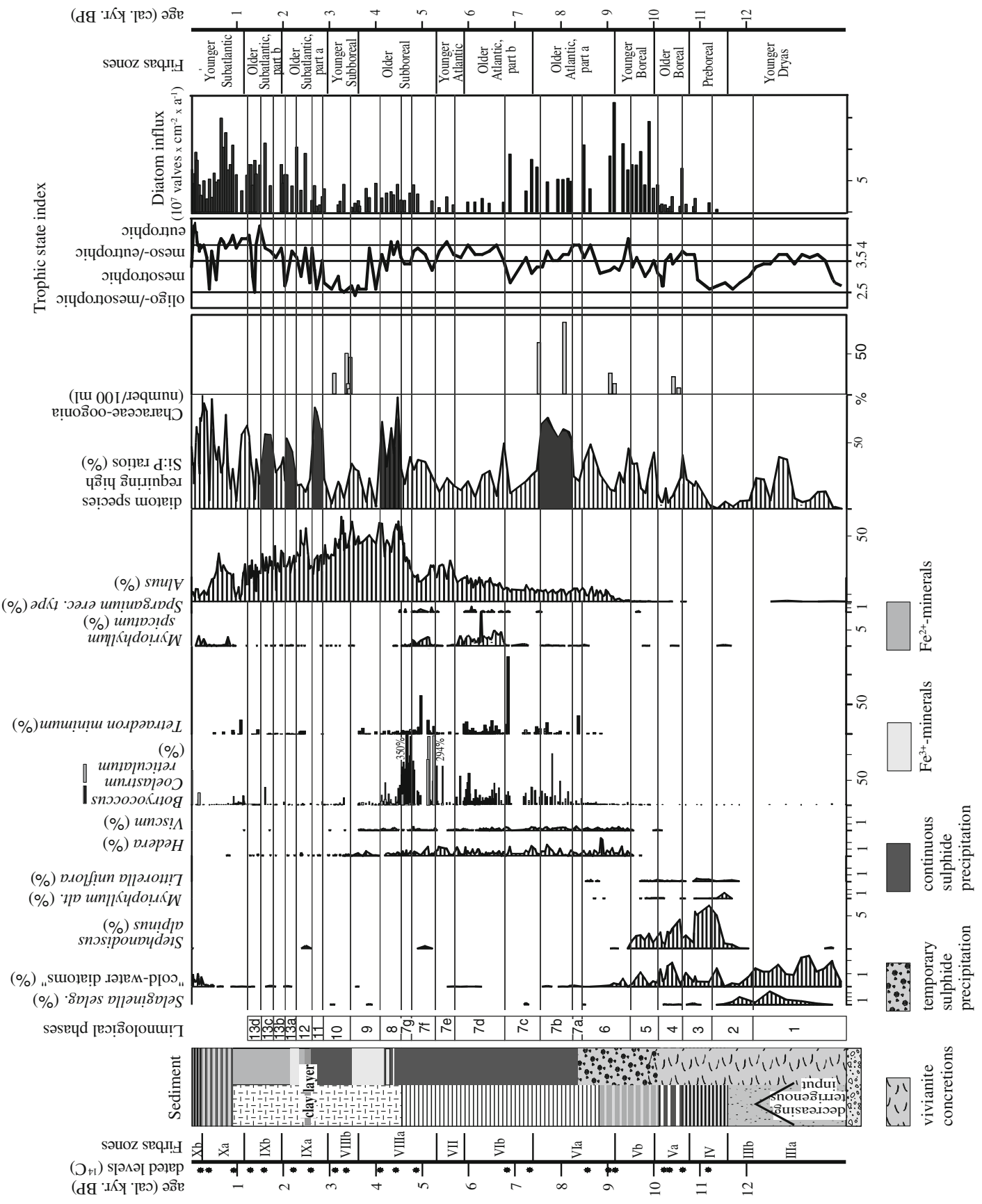

Fig. 11 Diagram of selected pollen, diatom and algae taxa, diatom-inferred trophic level and diatom influx. Diatoms, green algae, water- and land plants are ordered from left to right according to their significance in the course of time. Signatures of the sediment column see Fig. 7. Percentages are based on

are no true temperature indicators, but weak competitors which colonize extreme sites. Despite their low frequencies $(0.2-2.4 \%)$ they can, however, be the tree pollen sum (water- and land plants and green algae) or the total of diatom valves, respectively. Characeae oogonia are given as number per $100 \mathrm{ml}$ sediment. Darker hatching in the curve of diatoms requiring high Si:P-ratios indicates periods of inferred higher precipitation

considered to indicate cold conditions like the coldresistant lesser clubmoss Selaginella selaginoides which occurred at the same time. 
Preboreal (pollen zone IV, 11,600-10,770

cal. yr. BP)

The gradual transition from unstructured to laminated mud as well as shifts in the pollen and diatom spectra indicate the start of the Preboreal. The age of the zone III to IV boundary-between 11,600 and 11,555 cal. yr. BP, extrapolated from radiocarbon dates-is in good agreement with the results of the varve counts from Lake Steisslingen $(11,580$ cal. yr. BP; Lechterbeck 2000) and Holzmaar (11,600 cal. yr. BP; Zolitschka 1998).

Lamination became distinct since 11,470 cal. yr. BP. The lamination is often slightly disturbed (in most cases by sliding for a few millimetres). A marked disturbance $(11 \mathrm{~cm})$ occurred between 11,015 and 10,830 cal. yr. BP. Ground unrest due to newly forming sinkholes in the area might have caused these disturbances.

The onset of lamination indicates stagnation phases during the summer with temporary anaerobic conditions in the hypolimnion due to gradually increasing temperatures. Lasting anaerobic conditions in the hypolimnion can be ruled out as vivianite formation continued. Apparently the lake was dimictic now.

The pollen spectra indicate closed forests with mainly Betula and Pinus (Fig. 9) which reduced erosion. Littorella uniflora and Myriophyllum alterniflorum, both characteristic of the shoreweed communities (Littorelletea), grew along the shore of Lake Jues during the Preboreal (Fig. 11). They indicate clear and weakly acid, nutrient-poor water (Ellenberg 1996). This agrees with the calculated trophic state index (mesotrophic at the lower end). The warming was not yet sufficient to support a temperature-induced increase of bioproduction and strong development of plankton. Tychoplanktonic Fragilaria spp. (mainly F. brevistriata Grunow in van Heurck 1885 and $F$. robusta) continued to dominate the diatom spectra (limnological phase 2, Fig. 10, Table 8). However, cold water-adapted species decreased, but did not totally disappear. The presence of Myriophyllum alterniflorum, too, points to still relatively low water temperatures. Today this species occurs in cool waters of nordic-subatlantic regions (Oberdorfer 1994). Increasing abundances of Stephanodiscus alpinus indicate that the ice cover during winter still lasted for a long time. Stephanodiscus alpinus can survive long dark periods (Stoermer
1993), and therefore has a competitive advantage after periods of lasting ice cover (Hickel and Håkansson 1993). Hickel and Håkansson (1993) emphasize that Stephanodiscus alpinus is not a cold-water species, but rather a poor competitor for $\mathrm{P}$ and Si.

Limnological phase 3: The increase of diatom concentrations (mean $32 \times 10^{7}$ valves $/ \mathrm{cm}^{3}$ ) and of plankton species such as Cyclotella comensis/pseudocomensis and Asterionella formosa points to further rising summer temperatures since ca. 11,200 cal. yr. BP. The mean diatom influx was $2.4 \times 10^{7}$ valves $\times$ $\mathrm{cm}^{-2} \times \mathrm{a}^{-1}$. Meso- to eutrophic conditions since 10,900 cal. yr. BP indicate improved nutrient supply due to temperature-induced higher bioproduction and intensified remineralization. The warmer climate allowed a first, but limited expansion of elm.

Older Boreal (pollen zone Va, 10,770-10,020 cal. yr. BP)

The early part of the Boreal is characterized by the spread of hazel. Hazel invaded the existing birchpine-forests forming a dense undergrowth. Elm and oak trees remained rare (Fig. 9). Three different limnological phases $(3,4,5$, Table 8) are distinguished:

Limnological phase 3 had already begun at the end of the Preboreal, and continued during the first $\sim 150$ years of the Boreal. Stephanodiscus minutulus became a frequent member of the planktonic diatom assemblages (Figs. 10, 11). Thin section no. 1 (Table 2) proves the annual character of the lamination. Above the detrital winter layer there follows a layer of Chrysophyceae cysts with pollen of Betula and Pinus, occasionally a layer of Stephanodiscus minutulus (main bloom in spring), and an autumnal layer rich in phytoplankton and detritus.

Limnological phase 4: Between 10,620 and 10,100 cal. yr. BP, clastic rhythmites with reddish, grey, and yellow, partially graded minerogenic layers (1-65 mm thick) were deposited. Diatom and pollen content of the minerogenic layers differ much from that of the older sediment (Table 9). Littoral (periphyton, tychoplankton) and allochthonous (aerophilous and rheophilous) diatoms prevail in the minerogenic layers, fern spores are unusually frequent. These layers were probably deposited during episodes of thawing and/or heavy rainfall accompanied by floods. The colours of the minerogenic layers reflect the conditions 
Table 9 Pollen, spore and diatom percentages of various sediment types in time section 11,600-8,820 cal. yr. BP (unusual percentages are bold)

\begin{tabular}{|c|c|c|c|c|c|c|c|}
\hline \multirow[t]{2}{*}{ Age (cal. yr. BP) } & $\begin{array}{l}\text { Laminated } \\
\text { silty gyttja }\end{array}$ & $\begin{array}{l}\text { Laminated } \\
\text { silty gyttja }\end{array}$ & $\begin{array}{l}\text { Clastic } \\
\text { rhythmites }\end{array}$ & $\begin{array}{l}\text { Coloured } \\
\text { minerogenic } \\
\text { layers }\end{array}$ & $\begin{array}{l}\text { Laminated } \\
\text { silty gyttja }\end{array}$ & $\begin{array}{l}\text { Grey } \\
\text { minerogenic } \\
\text { layers }\end{array}$ & $\begin{array}{l}\text { Unstructured } \\
\text { silty gyttja }\end{array}$ \\
\hline & $\begin{array}{l}11,600-10,770 \\
\text { (Preboreal) }\end{array}$ & $\begin{array}{l}10,770-10,620 \\
\text { (Boreal) }\end{array}$ & \multicolumn{2}{|c|}{$\begin{array}{l}10,620-10,100 \\
\text { (Boreal) }\end{array}$} & \multicolumn{2}{|c|}{$\begin{array}{l}\text { 10,100-8,820 (Boreal, } \\
\text { Older Atlantic) }\end{array}$} & $\begin{array}{l}\text { ca. } 10,450 \\
\text { Boreal }\end{array}$ \\
\hline Plankton & 35 & 70 & 42 & 13 & 71 & 61 & 15 \\
\hline $\begin{array}{l}\text { Periphyton/ } \\
\text { Tychoplankton }\end{array}$ & 56 & 26 & 48 & 62 & 27 & 30 & 69 \\
\hline Aerophilous diatoms & 0.31 & 0 & 0.34 & 2.9 & 0.09 & 0.84 & 0.25 \\
\hline Rheophilous diatoms & 1.4 & 0.57 & 2 & 11 & 0.35 & 3.7 & 0.2 \\
\hline Polypodiaceae & 5.5 & 12 & 7.9 & 227 & 2 & 41 & 7.5 \\
\hline Corylus & 0.6 & 7.7 & 171 & 810 & 236 & 464 & 35 \\
\hline
\end{tabular}

Percentages are based on the tree pollen sum (Corylus, Polypodiaceae) or the total of diatom valves, respectively

after the time of inflow of the washed-in components (Lambert and Hsü 1979). The reddish (oxidized) layers must have been deposited during phases of circulation (see preceding chapter). Thin section no. 1 shows that since $10,620 \mathrm{cal}$. yr. BP the laminated sequence iswith increasing frequency-interrupted by minerogenic layers intercalated between the winterly detritus and the Chrysophyceae. The annual lamination is no longer distinct in thin section no. 2. Generally, however, the multicoloured minerogenic layers are followed by a diatom-Chrysophyceae layer and detritus above. Therefore the minerogenic layers are most likely the result of floods during winter and springtime, and thus are caused by thawing. At the same time and until 9,900 cal. yr. BP, birch, poplar and willow spread (Fig. 9), most likely indicating greater discharge and frequent shifts of the bed of the river Sieber which favoured softwood riparian forests. The planktonic species, except Stephanodiscus alpinus, diminished while tychoplankton and periphyton became dominant again. "Cold-water species" as well as rheophilous and aerophilous diatom species became more frequent since ca. 10,400 cal. yr. BP. A general warming started after 10,230 cal. yr. BP, but the indicators of less favourable climatic conditions did not vanish until 9,800 cal. yr. BP.

Lamination and the presence of vivianite concretions prove that the ecological conditions in the lake (dimictic, temporarily anaerobic hypolimnion) had not changed since the end of the Preboreal.

A 154-cm-thick layer of unstructured silty gyttja with a special pollen and diatom content interrupts the clastic rhythmites of limnological phase 4 at ca. 10,450 cal. yr. BP (Fig. 7). Corylus pollen is much less frequent (mean 35\%) than in the sediments above and below (236\%). The diatom spectra are dominated by littoral species, the plankton values are low (Table 9). These changes were probably caused by a slump of older sediments with little or no pollen of Corylus into the deep of the lake basin.

Limnological phase 5 started during the last years of the older Boreal and continued during the beginning of the younger Boreal. Above the rhythmites (limnological phase 4), laminated silty gyttja with numerous, merely grey, graded minerogenic layers (1-220 mm thick) follows, containing similar pollen and diatom floras as the clastic rhythmites of phase 2 . The diatom influx increased distinctly (Fig. 11). The increase of the coccal green alga Pediastrum boryanum indicates warmer summers (Raeder 1990). The grey (reduced) minerogenic layers were probably deposited during stagnation phases. Although dating from limnological phase 6 , thin section no. 3 resembles this sediment type. The two- to three-layered varves consist of a detritus layer deposited in winter, a phytoplankton layer formed in spring or summer (mainly Asterionella formosa, Cyclotella comensis/pseudocomensis, $C$. ocellata), and sometimes an additional layer with fragments of benthic diatoms and detritus. These littoral species were most likely washed into the lake by heavy summer or autumn rainfall like in the other, thicker grey minerogenic layers.

The spotty occurrence of (black) sulphides in the sediments indicates that deep circulation was 
temporarily hindered, possibly caused by decreasing wind exposure resulting from the formation of a sheltering broad-leaved forest belt around the lake. Now holomictic and meromictic phases alternated.

Younger Boreal (pollen zone $\mathrm{Vb}, 10,020-9,160$ cal. yr. BP) and Older Atlantic (pollen zone VI, 9,160-5,910 cal. yr. BP)

During the Younger Boreal closed deciduous forests replaced the birch-pine-woods in the vicinity of Lake Jues (Fig. 9). In addition to oak and elm, smallleaved lime (Tilia cordata), a species adapted to summer-warm sites, gained in importance since 9,700 cal. yr. BP. From ca. 9,500 cal. yr. BP mistletoe (Viscum) indicating warm summers and ivy (Hedera) sensitive to strong frost and therefore indicating mild winters became more frequent in the forests (Fig. 11).

Farming spread in Central Europe since about 7,650 cal. yr. BP (Linear Pottery; Behre 1995). At about the same time, the forests around Lake Jues were affected for the first time by human activity (Fig. 9). Human influence remained weak, however, during all of the Neolithic period (Voigt 2006).

The sediments deposited during the Younger Boreal and the Older Atlantic are laminated throughout. As before-since 10,100 cal. yr. BP and until 8,820 cal. yr. BP-a silty gyttja rich in plantmacrofossils and with numerous grey minerogenic layers was deposited (Table 9) indicating that heavy summer or autumn rainfall continued to occur. Subsequently the sedimentation of minerogenic layers ended. Diatom gyttja with less macrofossils follows above the silty gyttja.

The increasing importance of the thermophilous woody taxa (Tilia cordata, Hedera, Viscum) since 9,700 cal. yr. BP coincides with changes of the water plant and diatom floras (Figs. 10, 11, Table 8) at the transition from limnological phase 5 to 6 . Around 9,700 cal. yr. BP Myriophyllum alterniflorum and Littorella uniflora disappeared from Lake Jues. About 200 years later, with the beginning of limnological phase 6, the "cold water diatoms" mentioned before, and Stephanodiscus alpinus decreased significantly. Planktonic diatoms became more frequent again and more diverse at the same time. Since 9,500 cal. yr. BP Cyclotella ocellata, and since 8,600 cal. yr. BP also Cyclotella radiosa, Fragilaria delicatissima, and
F. tenera became more common, while Asterionella formosa, Cyclotella comensis/pseudocomensis, and Stephanodiscus minutulus were still present.

Limnological phase 6 is represented by thin sections nos. 3 and 4 . In thin section no. $3(9,245-$ 9,120 cal. yr. BP) only one diatom bloom with Asterionella, Stephanodiscus minutulus, and Cyclotella spp. occurred in spring and early summer layers. In summer probably other algae thrived, among them Pediastrum colonies. In thin section no. 4 (8,920-8,690 cal. yr. BP) two annual diatom blooms can be distinguished: Asterionella (Si-demanding) and/or Stephanodiscus minutulus (requiring much P) reached a springtime maximum depending on the Si:P-ratio. The Si:P-ratio is determined by the circulation pattern (P-reflux from the hypolimnion) and the amount of precipitation (Si-input). Extended periods of deep circulation and/or low winter and spring precipitation provide high phosphorus concentrations and a low Si:P-ratio. Under opposite conditions, the phosphorus flux decreases and/or silicon concentrations increase so that a high Si:P-ratio results (Bradbury and Dieterich-Rurup 1993). Subsequent to the following clear water phase a Cyclotella bloom occurred. Cyclotella species tolerate low $\mathrm{Si}$ - and P-concentrations and typically occur during summer stratification because they are favoured by stable light and temperature conditions (Fahnenstiel and Glime 1983; Stoermer 1993). The autumnal diatom phase could not be identified in the thin section and is probably obscured by the detritus layer.

Limnological phase 7: A distinct change of the summer algae assemblages started ca. 8,400 cal. yr. $\mathrm{BP}$ with the proliferation of the coccal green algae Botryococcus and Tetraedron minimum (Fig. 11). Coccal Chlorophyceae prosper in small eutrophic lakes during periods of high insolation favouring stable summer stratification (Reynolds 1984). During long lasting periods of fine weather Raeder (1990) observed blooms of Tetraedron, Coelastrum, Pediastrum and other coccal green algae. This green-algaephase lasted until 4,550 cal. yr. BP and is divided into 7 subphases.

The diatom assemblages of subphase $7 \mathrm{a}$ are still similar to those of limnological phase 6 .

Subphase $7 b$ : High relative abundances of Asterionella and only small amounts of Stephanodiscus minutulus, indicate little phosphorus reflux from the sediment due to incomplete circulation and/or increased 
Si-supply, likely caused by more precipitation in springtime (Bradbury and Dieterich-Rurup 1993).

Subphase 7c: The prevalence of spring diatoms decreased (thin section no. 5). Other algae, not identifiable in the thin section, and Chrysophyceae dominated the spring-bloom. A major growth of diatoms (Cyclotella comensis/pseudocomensis or $C$. ocellata) occurred in summer only (Fig. 10).

Subphase $7 d$ : The sediments deposited between 6,750 and 5,820 cal. yr. BP contain greater amounts of pollen of Myriophyllum spicatum and Sparganium erectum-type, both members of the emergent vegetation (Fig. 11). This might be due to erosion of littoral deposits following a lowering of the lake level. Increasing percentages of periphyton and tychoplankton and a small diatom influx reflect a reduced growth of the planktonic diatoms. Less precipitation and, hence, reduced $\mathrm{Si}$-inflow into the lake probably prevented a distinct spring diatom-bloom.

Holomictic and meromictic phases continued to alternate until about $8,300 \mathrm{cal}$. yr. BP as shown by spotty distribution of dark sulphide in the sediment (limnological phases 5 and 6, Fig. 11). However, the meromictic phases became gradually longer, so that the oxygenation at the sediment/water interface was no longer sufficient for the formation of vivianite after 9,900 cal. yr. BP. While the phosphorus concentrations in the epilimnion were high during holomictic phases (meso- to eutrophic status), phosphorus reflux from the sediment and hypolimnion was hindered during meromixis causing reduced availability of phosphorus in the epilimnion (mesotrophic status). The obvious trend towards persistent meromixis and thus towards depletion in nutrients was enforced after 8,400 cal. yr. BP (limnological phase 7), when continuous warm weather caused longer lasting stagnation periods with blooms of coccal green algae and the accumulation of great quantities of organic substances in the hypolimnion (Sommer 1994, biogenic meromixis). The now black colour of the sediment (sulphides) is indicative of anoxic conditions. The lake did not return to oligomictic conditions until about 6,660 cal. yr. BP as indicated by the then increasing trophic state. At that time (subphase 7d) circulation was probably favoured by longer spring periods and/or shorter winters. Sulphide precipitation, however, continued, indicating lasting anoxic conditions in the hypolimnion, probably due to high production of organic material and high mineralization rates.
Younger Atlantic (pollen zone VII, 5,910-5,300 cal. yr. BP) and Older Subboreal (pollen zone VIIIa, 5,300-3,620 cal. yr. BP)

Deciduous forests thrived in the area around Lake Jues during the Younger Atlantic and the Older Subboreal (Fig. 9). Mistletoe and ivy were common at that time (Fig. 11). Although beech percentages increased during zone VIIIa, this species did not reach any importance in the forests for the next 1,700 years. Forest communities were more and more affected by human impact as shown in zones VII and VIIIa comprising Middle, Young and Late Neolithic (Voigt 2006; Fig. 9). Anthropogenic influence continued around Lake Jues until about 4,170 cal. yr. BP and probably slightly increased up to this time. Between 4,170 and 3,620 cal. yr. BP, i.e. by the end of zone VIIIa, human settlement ceased at Lake Jues.

Sedimentation of laminated diatom gyttja continued during the Younger Atlantic and the Older Subboreal. In zone VII plant macrofossils are extremely rare. After about 4,550 cal. yr. BP greater quantities of fine plant detritus and macrofossils were preserved.

During pollen zones VII and VIIIa Lake Jues experienced five different floristic and limnological phases (7e, f, g, 8 and 9):

Subphase 7e: A change of the aquatic vegetation of Lake Jues occurred about 200 years after the start of the Younger Atlantic, simultaneously with the expansion of alder (Alnus glutinosa, Fig. 11). Lower values of Myriophyllum spicatum and Sparganium erectum-type point to less erosion of littoral material and a rise of the lake level. Though low diatom influx rates and high periphyton values still reflect a weak plankton development, higher abundances of Stephanodiscus minutulus indicate a spring diatom bloom, probably followed by a bloom of Cyclotella radiosa (lower Si- and P-requirements). Mass development of green algae became rarer due to wetter summers. Increased precipitation led to elevated water levels and to the rise of groundwater which favoured the expansion of alder. Despite the climatic change, mixing and trophic state conditions remained unchanged as shown by the trophic status (meso- to eutrophic) and the continuously black sediment.

Subphase 7f: Higher diatom influx and lower periphyton and tychoplankton percentages reflect the increased prevalence of diatoms in the plankton 
assemblages. Thin section no. 6 shows that varves became more complex. The early spring succession started with the dominance of Cyclotella radiosa, replaced by Stephanodiscus minutulus or Asterionella formosa depending on the Si:P-ratio. This might indicate low Si- and P-concentrations due to warm and dry conditions during early spring, followed by more humid and/or cooler weather conditions, resulting in increasing $\mathrm{P}$ - and/or Si-concentrations. Lower $\mathrm{Si}$ - and P-concentrations in summer favoured Cyclotella comensis/pseudocomensis and C. radiosa. Also green algae proliferated again in summer. In addition to Botryococcus and Tetraedron minimum, Coelastrum reticulatum was temporarily very abundant $(5,250-5,000$ cal. yr. BP), a species found today more frequently in the tropical rather than in the temperate zone (L. Krienitz, pers. communication). A weak diatom bloom of Fragilaria crotonensis and F. ulna var. acus followed in autumn.

The distinct blooms of green algae, especially the bloom of Coelastrum reticulatum, indicate long lasting dry and warm summer weather. This caused a lower water level between 5,150 and 4,770 cal. yr. BP, as reflected by higher pollen percentages of Myriophyllum spicatum and Sparganium erectum-type, and lower ones of Alnus (Fig. 11). During the Coelastrumstage of this period, mesotrophic conditions point to meromixis. Subsequently increasing nutrient concentrations indicate a shift towards oligomixis. Consequently, the hypolimnion stayed anoxic.

Subphase 7g: The mass development of green algae even increased (up to $350 \%$ Botryococcus relative to the AP-sum) during the warm and sunny summers, and nutrient concentrations decreased temporarily due to meromixis. Although warm conditions continued to prevail, higher precipitation, presumably during winter and spring, supported the spread of Alnus glutinosa. Groundwater and lake level rose again, as shown by decreasing pollen percentages of the littoral species Myriophyllum spicatum and Sparganium erectum-type.

Limnological phase 8: Asterionella dominated during the spring bloom, reflecting a rise of the $\mathrm{Si} /$ P-ratio. Summer blooms of green algae became rarer because of cooler and/or wetter summers (Fig. 11). Temporarily eutrophic conditions point to more frequent holomictic phases due to longer transitional seasons. The eutrophic conditions and the concurrent high biomass production caused anoxia in the hypolimnion and in the pore water and favoured the continuous formation of sulphides in the sediment. The decomposition of the litter slowed down, as indicated by more well-preserved allochthonous land plant remains. Subsequently, the supply of dissolved phosphorus decreased, and the lake became mesotrophic since about 4,300 cal. yr. BP. In summer Cyclotella comensis/pseudocomensis increased (Fig. 10), because of low P and Si concentrations. Reddish sediment colours between 4,300 and 4,230 cal. yr. BP prove temporary oxic conditions in the hypolimnion.

Limnological phase 9: Decreasing diatom influx values indicate a weaker primary production caused by the continuous nutrient depletion. Due to the weak production and/or due to relatively short periods of stable stratification, the hypolimnion again became oxic between 4,120 and 3,440 cal. yr. BP as shown by reddish colours of the sediment. The spring succession started now with the Si-preferring species Fragilaria delicatissima and/or F. capucina var. gracilis. Fragilaria delicatissima is a species adapted to low phosphorus concentration, scant light intensity and low temperatures (Hofmann 1994). In summer Cyclotella comensis/ pseudocomensis still dominated the plankton, sometimes accompanied by $C$. radiosa or $C$. ocellata.

Younger Subboreal (pollen zone VIIIb, 3,620-2,960 cal. yr. BP) and Older Subatlantic (pollen zone IX, 2,960-1,160 cal. yr. BP)

With the start of the Younger Subboreal beech began to proliferate (Fig. 9). Until 2,960 cal. yr. BP beech had replaced the other deciduous tree species at most of the well-drained sites and dominated the forests (Beug 1992; Beug et al. 1999; Chen 1988). In the shady beech forests flowering Hedera became rare. Viscum, an indicator of warm summers, disappeared completely, despite the fact that its prominent host trees, Populus, Salix, Tilia, Betula and Acer (Oberdorfer 1994), were initially not much affected by the spreading of beech. Although the spread of beech was probably influenced by human activities, beech was certainly favoured by climatic factors such as more humid summers and fewer late frosts (Voigt 1996).

Settling around Lake Jues started anew during the Early Bronze Age after the interruption at the end of the Older Subboreal (Fig. 9). Human influence continued almost uninterrupted during the following two 
millennia. Scanty in the beginning, it became more distinct after 3,310 cal. yr. BP, but decreased again after 2,245 cal. yr. BP (Voigt 2006).

There are seven limnological phases $(10,11,12$, $13 \mathrm{a}-\mathrm{d})$ reflecting climatic change as well as human impact:

Limnological phase 10: The plankton communities were dominated by nearly pure Cyclotella blooms (Fig. 10). Increasing abundances of Cyclotella spp. with lower Si-requirements even during springtime points to decreased $\mathrm{Si}$ concentrations and lower precipitation. Strongly reducing conditions in the hypolimnion are indicated by the black colour of the sediment. Slightly warmer summers allowed stratification to last longer so that oligo- or meromictic conditions returned. The nutrient concentrations remained unchanged at a low level until around 3,200 cal. yr. BP. For the first time since zone VIa Characeae (Chara globularis or Ch. delicatula) appeared again in the littoral (Fig. 11). According to Melzer (1999) both species do not occur in eutrophic waters. Slightly increased phosphorus concentrations, presumably linked to Younger Bronze Age settlement activities, caused a decline of the Characeae, ending with their absence after 3,115 cal. yr. BP.

Limnological phase 11: An increase of total precipitation, starting at the end of the Younger Bronze Age settlement, is indicated by higher abundances of Si-demanding diatoms such as Asterionella formosa, Fragilaria delicatissima and F. capucina var. gracilis while Cyclotella species, characteristic of the previous assemblages, decreased probably due to unfavourable weather.

Due to more frequent deep mixing, dissolved nutrients, which had accumulated during the preceding period, were re-suspended into the epilimnion leading to a temporary rise in the trophic state. Concurrent with the higher organic production, the sediment-water-interface continued to be anoxic (black sediment) during this period. Subsequently, unfavourable climate and declining human impact at the transition from Bronze to Iron Age led to lower nutrient concentrations (Figs. 9, 11).

Limnological phase 12: From 2,700 cal. yr. BP a settlement phase began at Lake Jues, which lasted 440 years (Voigt 2006). Although until 2,500 cal. yr. BP land use was as weak as during the preceding Bronze Age settlement phase, the beginning of the new phase coincides with eutrophication, probably caused by human activities. This assumption is supported by the temporary abundance of the pollution-tolerant Nitzschia paleacea between 2,700 and 2,600 cal. yr. BP (Fig. 10).

During the Iron Age a settlement probably existed in immediate vicinity of the lake. Clearings, arable farming and meadow culture led to destabilization of soils and, hence, to erosion. A $2 \mathrm{~cm}$ thick clay layer deposited around 2,500 cal. yr. BP reflects considerable disturbances along the shore of Lake Jues. Numerous thinner clay layers prove intensified erosive processes. Probably due to construction work on the shore of Lake Jues, the circulation pattern changed to annual holomixis which the lake retained until medieval times as indicated by the greenish colour of the sediment. Phosphorus-reflux from the sediment and anthropogenic supply of phosphorus and nitrogen caused eutrophication of the lake and an increase of primary production. The high organic production and/or lasting phases of stable summer stratification resulted in high oxygen-consumption in the hypolimnion and the reduction of Fe-oxides, but not in the reduction of sulphate. For this period it is not possible to differentiate clearly between anthropogenic influence and climate signals. The plankton assemblages reflect the strong human impact of the Iron-Age-settlement. Eutrophication favoured Stephanodiscus minutulus (requiring low Si:P-ratios) in spring and Pediastrum boryanum blooms in summer (Fig. 10). Nitrogen supply and/or organic pollution likely favoured Nitzschia paleacea. Although Cyclotella comensis/pseudocomensis does not tolerate eutrophication (Hofmann and Schaumburg 2005e, f), this species also reached high abundances, perhaps following the P-consuming blooms of Stephanodiscus minutulus or Pediastrum boryanum. Cyclotella comensis/pseodocomensis probably also responded to nitrogen supply. According to Wolin et al. (1988) C. comensis prefers somewhat higher nitrate-concentrations. Chrysophyceae, which had always been part of the algal associations until this time, became insignificant now due to eutrophication (Kristiansen 2005).

Limnological phase 13: Settlement at Lake Jues declined since 2,245 cal. yr. BP (Fig. 9). The forests regenerated, but were still used as coppiced woods (spread of Carpinus) and as forest pasture. During the Migration Period and the Early Middle Ages the area 
around the lake was almost deserted. High abundances of Si-preferring diatoms (Fragilaria capucina var. gracilis, Asterionella formosa, and/or Fragilaria crotonensis) indicate increased Si-input caused by wetter conditions between 2,280 and 2050 (subphase 13a) and between 1,800 and 1,500 cal. yr. BP (subphase 13c). At least from 1,600 to $1,500 \mathrm{cal}$. yr. BP (the period which comprises thin section no. 7) the spring diatom layer was followed by a layer rich in humus, probably caused by heavy precipitation in late spring or early summer (during the beech bloom), and a summer/fall layer mainly with Cyclotella ocellata. Nutrient concentrations were no longer sufficient for Pediastrum boryanum to grow. In between these two wetter phases a period with probably warmer and dryer summers is indicated by high percentages of Cyclotella spp. (subphase 13b). From 1,500 cal. yr. BP decreasing percentages of Si-preferring diatoms reflect lower precipitation (subphase 13d).

Coinciding with the abandonment of cultivation, stable summer stratification occurred only rarely until 2,100 cal. yr. BP as shown by reddish sediment colours (subphase 13a). With a few exceptions the nutrient concentrations remained high (meso- to eutrophic), which might be the result of holomixis as well as of continued soil erosion reinforced by a wetter climate and by forest use. Following strong eutrophication the recovery of a lake from high phosphorus loads can take a long time (Hausmann et al. 2001). In the Swiss Seebergsee oligotrophication could not take place before temperatures increased at the end of the Little Ice Age and triggered the onset of meromixis (Hausmann et al. 2001). However, the diatom-inferred eutrophy of Lake Jues around 1,480 cal. yr. BP is questionable, because in this case the trophic state index is mainly based on Nitzschia paleacea with a frequency of $6 \%$, while trophic-tolerant species dominated the assemblage with $89 \%$. In contrast, the eutrophication after 1300 cal. yr. BP (=AD 650), indicated by Nitzschia paleacea and Stephanodiscus minutulus with values $>30 \%$, may already have been caused by early medieval settlement which shows up in the pollen spectra since 1,240 cal. yr. BP. Thus this last phase is transitional to the medieval expansion of settlement during the Younger Subatlantic. Subsequently the limnological status of the lake was strongly influenced and changed by human activities.
Climatic reconstruction

The sediments of the Younger Dryas in Lake Jues were deposited under cold, arctic conditions. Diatom and pollen records provide evidence of long, cold winters that alternated with short, cool summers (limnological phases 1 and 2). Decreasing deposition of terrigenous material indicates a gradual warming which accelerated at the beginning of the Preboreal. The Preboreal temperature increase appears not as abrupt in the record of Lake Jues as it is documented in other archives (Dansgaard et al. 1989; von Grafenstein et al. 1999). Compared with the Younger Dryas, summers lasted longer in Preboreal times, but were still relatively cool. Summers did not become warmer before 11,200 cal. yr. BP (limnological phase 3). Winters continued to be cold resulting in a longlasting ice-cover on the lake. A cooler phase lasting from 11,360 to $11,090 \mathrm{cal}$. yr. BP as suggested by Behre (1978) and Zolitschka (1998) cannot be proven in Lake Jues, due to minor sediment disturbances and insufficient temporal resolution in this part of the diatom and pollen diagrams.

The progressive warming in the late Preboreal continued during the first 150 years of the Boreal. A cooling phase (limnological phase 4) apparently started around 10,620 cal. yr. BP, culminating between ca. 10,550 and 10,230 cal. yr. BP (Fig. 12). Summers were cooler again, and long, snow-rich winters caused frequent flooding during the spring melt of snow. A cooler phase during this period is also detected in Switzerland and France (Haas et al. 1998; Lotter et al. 1992; Magny 2004) and at other places in Germany (Zolitschka 1998). The melting of the Scandinavian glaciers is assumed to have triggered the cooling process by suppression of the North Atlantic current (Björck et al. 2001, Zolitschka 1998).

Since 10,100 cal. yr. BP temperatures rose gradually while floods occurred as frequently as before, but were now caused by heavy rainfall during summer (limnological phases 5 and 6). Since 8,820 cal. yr. BP rainfall was more uniformly distributed throughout the year. Although there is no evidence for less total precipitation, this cannot be excluded. According to Kalis et al. (2003) the Boreal was a period with higher precipitation, followed by dryer conditions during the Older Atlantic. However, the start of a dryer Atlantic period is not consistently dated in German archives (Kalis et al. 2003). High 


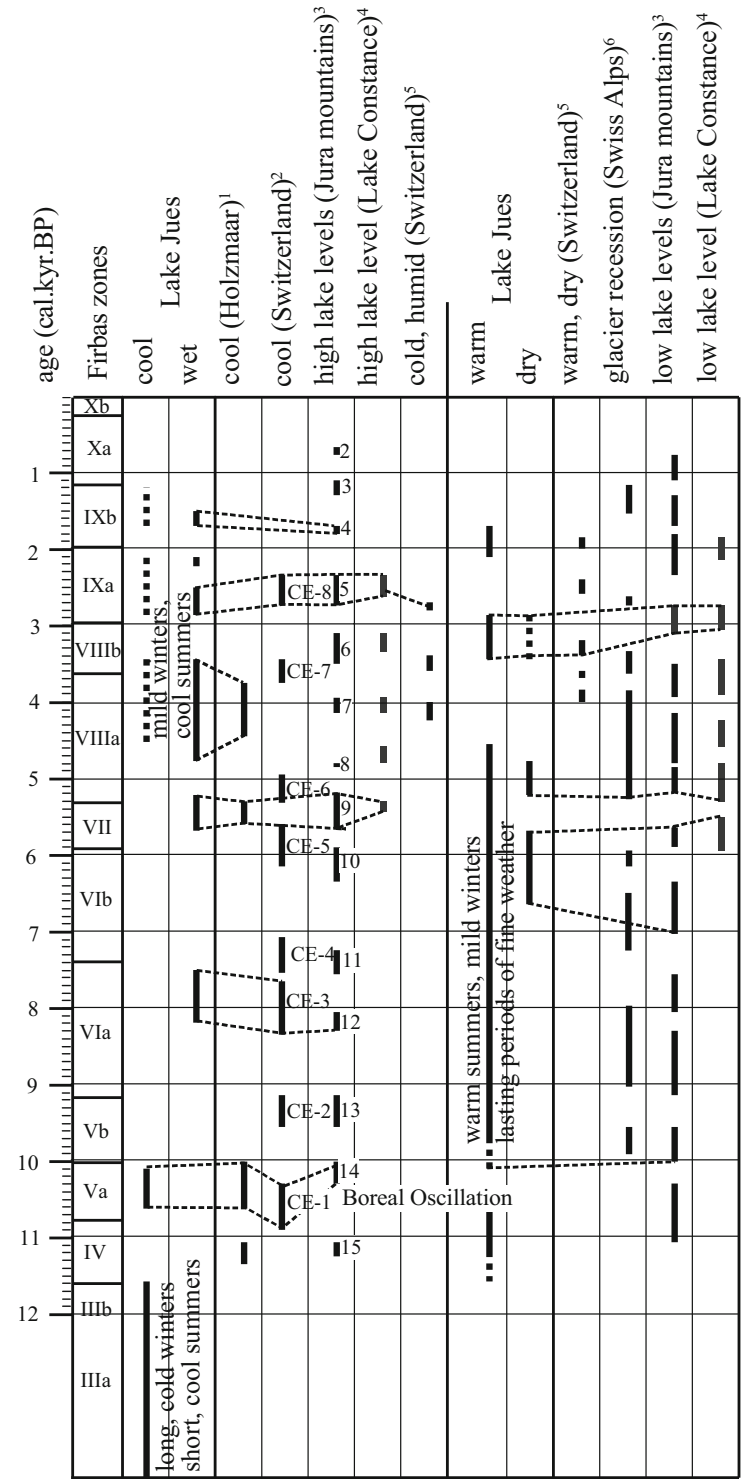

Fig. 12 Climatic changes at Lake Jues and other European sites. Coinciding changes are marked by dashed lines. ${ }^{1}$ Zolitschka 1998, Zolitschka and Negendank 1997; ${ }^{2}$ Haas et al. 1998; ${ }^{3}$ Magny 2004; ${ }^{4}$ Schlichtherle et al. 2000; ${ }^{5}$ Tinner et al. 2003; ${ }^{6}$ Hormes et al. 2001. Episodes with high lake levels in the French and Swiss Jura mountains are numbered according to Magny (2004). Cold phases recorded from Switzerland are numbered according to Haas et al. (1998)

lake levels occurred at Hämelsee (Fig. 1) until 8,800 cal. yr. BP, only interrupted by a short phase with a low lake level between 9,340 and 9,250 y cal. BP (Kleinmann et al. 2000 b).

Warm summers (since 9,700 cal. yr. BP) and mild winters (since 9,500 cal. yr. BP) characterize the following millennia. Long periods of fine summer weather were typical of the time between 8,400 and 4,550 cal. yr. BP (limnological phase 7). Stable warm and dry conditions between 8,000 and 4,000 cal. yr. BP were also proven for northern Europe (Eronen et al. 1999). The global cooling event around 8,200 cal. yr. BP (Alley et al. 1997; Haas et al. 1998; Magny 2004; von Grafenstein et al. 1998) is not detectable in the Lake Jues record. However, an increase of precipitation probably occurred between 8,200 and 7,500 cal. yr. BP (Fig. 12, limnological subphase 7b). For the same time a more humid phase is described from Swiss sites (CE-3, Haas et al. 1998) and from southern Sweden (around 8,200 cal. yr. BP; Hammarlund et al. 2005).

Between 6,750 and 5,700 cal. yr. BP warm summers and probably decreased precipitation caused a lowering of the water level (limnological subphase $7 \mathrm{~d})$. Lower levels of Hämelsee occurred between 7,000 and 6,750 cal. yr. BP and between 6,200 and 5,950 cal. yr. BP (Kleinmann et al. 2000 b). Very low lake levels were stated between ca. 7,000 and 5,650 cal. yr. BP at sites in the French and Swiss Jura Mountains, interrupted, however, by high water levels between 6,350 and 5,900 cal. yr. BP (Magny 2004, Fig. 12). In comparison, the recession phases of Alpine glaciers (Hormes et al. 2001) do not coincide exactly with this warm period (Fig. 12). A wetter phase around 6,000 cal. yr. BP could not be found in Lake Jues, while in the Upper Harz Mountains a cooler phase is indicated by increased peat growth between 6,460 and 5,810 cal. yr. BP (Beug et al. 1999). From the Alps (CE-5; Haas et al. 1998) and from northern Europe (Berglund 2001) a cool phase is known around 5,900 cal. yr. BP.

In the Lake Jues record a more humid phase is shown for the time between 5,700 and 5,250 cal. yr. BP only (limnological subphase 7e). This period lies between the two cool and humid phases CE-5 and CE-6 as known from the Alps (Haas et al. 1998). However, it begins almost simultaneously with a dendrochronologically well dated high water level in the Jura Mountains (episode 9, Magny 2004). For Lake Constance, too, a high water level is inferred around 5,400 cal. yr. BP (Schlichtherle et al. 2000). Zolitschka (1998) assumes a wetter and/or cooler phase between 5,600 and 5,300 cal. yr. BP. According to Berglund (2001) wet/cool conditions occurred around 5,500 cal. yr. BP in northern Europe. 
Since 5,250 cal. yr. BP and until 4,770 cal. yr. BP summers became dryer and very warm again, causing another drop of the level in Lake Jues (limnological subphase $7 \mathrm{f}$ ). The beginning of this warmer period coincides with the start of a period of low lake levels at Lake Constance (Schlichtherle et al. 2000) and in the Jura Mountains (Magny 2004), with the beginning of a recession phase of Alpine glaciers (Hormes et al. 2001), but also with a cool and humid phase in the Alps (CE-6; Haas et al. 1998, Fig. 12). During the following 200 years, until 4,550 cal. yr. BP, summers continued to be warm, but the climate became more humid causing a rise of the lake level (limnological subphase $7 \mathrm{~g}$ ).

Starting 4,550 cal. yr. BP lower summer temperatures, more precipitation, and less frequent late frost reflect the gradual change from a continental to a more oceanic climate (limnological phase 8 and 9). A rather wet/cool phase is reported for northern Europe around 4,500 cal. yr. BP by Berglund (2001), which coincides with a maximum of ice rafting debris (IRD event; Bond et al. 2001). According to Berglund (2001), a change from more continental to oceanic conditions began around 3,800 cal. yr. BP. At Lake Holzmaar the time between 4,450 and 3,750 cal. yr. BP was characterized by increased precipitation and/ or lower temperatures (Zolitschka and Negendank 1997). In Switzerland a short cold-humid phase is reported for the period between 4,250 and 4,050 cal. yr. BP (Tinner et al. 2003). However, the time between ca. 5,000 and 3,800 cal. yr. BP is usually considered as a warm period. This is indicated, for example, by low lake levels in the Alps (Haas et al. 1998; Voigt 1996), in the Jura Mountains (Magny 2004) and in southern Sweden (Digerfeldt 1998), and by retreating glaciers in the Alps (Hormes et al. 2001; Röthlisberger 1986). Only after 3,800 cal. yr. BP (Haas et al. 1998), after 3,500 cal. yr. BP (Magny 2004; Voigt 1996), or after 3,200 cal. yr. BP (Digerfeldt 1998), respectively, the climate became cooler and/or wetter.

The trend towards a cooler and wetter, more oceanic climate continued during the Younger Subboreal (zone VIIIb) and the Older Subatlantic (zone IX), however, interrupted by dryer and warmer phases, which correspond with increased settlement intensity (Voigt 2006). A warmer and less humid period occurred between 3,450 and 2,850 cal. yr. BP (limnological phase 10). Warmer phases around 3,000 cal. yr. BP recorded from Austria (Schmidt et al. 2007), Switzerland (Haas et al. 1998; Tinner et al. 2003) and from the Jura Mountains (Magny 2004) are in phase with these results. According to Maise (1998) there were two warm phases lasting from 3,600 to 3,400 cal. yr. BP and approximately between 3,300 and 2,800 cal. yr. BP in Central Europe.

An increase of total precipitation is indicated for the time between 2,850 and 2,650 cal. yr. BP (limnological phase 11), the transition period from the Bronze Age to the Iron Age. This wet phase corresponds well with high lake levels in the Jura Mountains (episode 5, Magny 2004) and at Lake Constance (Schlichtherle et al. 2000). Schmidt et al. (2007) assume cooler and more humid winters in the southern Austrian Alps between 2,650 and 2,350 cal. yr. BP. The century 2,800 to $2,700 \mathrm{cal}$. yr. BP is generally described as a cool phase with major consequences on the settlement structure of Central Europe (Berglund 2001; Haas et al. 1998; Kilian et al. 1995; Maise 1998; Tinner et al. 2003; van Geel et al. 1996, 1999, 2004; van Geel and Berglund 2000; Zolitschka 1998; Zolitschka et al. 2003).

During the following period (2,500-2,280 cal. yr. BP, limnological phase 12) climate signals are obscured by strong human impact. However, the extension of settlement at Lake Jues during this period was probably favoured by a warmer climate (Voigt 2006).

Changeable summers and higher precipitation are indicated by the Lake Jues record between 2,280 and 2,100 cal. yr. BP (limnological subphase 13a). According to Maise (1998) a cooler phase similar to that around 2,800 cal. yr. BP started around 2,350 cal. yr. BP. Röthlisberger (1986) described glacier advances in the Alps for this period. Tinner et al. (2003) suggest a cool, humid phase around 2,150 cal. yr. BP.

According to the sediment record of Lake Jues summers became warmer again since 2,100 cal. yr. BP. Another humid phase occurred between 1,700 and 1,500 cal. yr. BP and probably coincides with the climatic deterioration of the Migration Period (Berglund 2001; Tinner et al. 2003; Zolitschka et al. 2003). According to Magny (2004) a short phase with high lake levels occurred between 1,800 and 1,700 cal. yr. BP (episode 4). With the beginning of the Middle Ages human and climate signals cannot be separated any longer. 


\section{Conclusions}

Fossil diatom assemblages can be used, as indicators of trophic status and circulation patterns of lakes. More detailed information can be gained from the study of the annual diatom succession as preserved in laminated sediments and visible in thin sections. The value of fossil diatom assemblages for reconstructions increases when combined with other proxies, e.g. pollen, other algae, sediment characteristics and ${ }^{14} \mathrm{C}$ dates.

The Lake Jues ecosystem, as well as the surrounding land vegetation, were strongly affected by climate variability, and thus enabled us to reconstruct the Holocene climate. Our results are in good agreement with those recorded from other European regions, although discrepancies exist concerning the timing of events. Events with age discrepancies within the $2 \sigma$ range of our radiocarbon dates are considered contemporaneous. Larger differences exist between 4,500 and 3,500 cal. yr. BP, when low lake levels in Austria, Switzerland and France coincide with rather cool and humid conditions further north. Further detailed investigations of the sediments of Lake Jues, but also at other German sites will be necessary to resolve the underlying reasons.

According to the Lake Jues record, the Holocene is subdivided into two main climatic periods:

1. The early and middle Holocene (until about 4,550 cal. yr. BP) with a still more continental climate. This part of the Holocene is further subdivided into four periods, the warming of the Preboreal, the Boreal between 10,620 and 10,100 cal. yr. BP with a subarctic climate, the late Boreal and the early Atlantic with a warmer climate and frequent flooding events (oceanic), and the Atlantic between 8,800 and 4,550 cal. yr. BP with very warm and temporarily dry summers and mild winters (tentatively Mediterranean).

2. The late Holocene between 4,550 and 1,240 cal. yr. BP with a gradual change to a more oceanic climate with cooler and more variable summers, higher precipitation and fewer late frosts, including several phases of warmer and dryer weather.

The study of Lake Jues provided a well dated, continuous and highly sensitive environmental and climatic reconstruction of the Holocene for the mid-latitudes in Central Europe and should serve as an important link between the better investigated neighbouring regions.

Acknowledgements The authors are deeply indepted to the coring team of 1995, Jürgen Schneider, Franz Wombacher, Tatjana Bukowski, Jürgen Meyer, Anja Speiser and Dieter Wehmeyer. Christa Herking provided part of the pollen count, Felix Bittmann helped with the identification of macrofossils. Dirk Heinrich identified the bones of red deer. Horst LangeBertalot, Gabriele Hofmann and Rolf Klee assisted R.V. through the identification of the diatoms. AMS radiocarbon dates were provided by Pieter M. Grootes. Klara Buß and Ingrid Jüttner improved earlier versions of the manuscript. Our sincere thanks go to all of our colleagues and helpers. We acknowledge with thanks the helpful reviews and comments by John Smol, Felix Bittmann and an anonymous limnologist, and the meticulous last corrections by editor Mark Brenner. The studies on Lake Jues were supported by the German Science Foundation as part of the Priority Program "Changes of the Geo-Biosphere during the last 15,000 years" (Project Nrs. Me 267/41, Gr 1067/2).

Open Access This article is distributed under the terms of the Creative Commons Attribution Noncommercial License which permits any noncommercial use, distribution, and reproduction in any medium, provided the original author(s) and source are credited.

\section{References}

Alley RB, Mayewski PA, Sowers T, Stuiver M, Taylor KC, Clark PU (1997) Holocene climatic instability: a prominent, widespread event 8200 yr ago. Geology 25:483-486

Baier J (1997) Die Sedimente des Jues-Sees in Herzberg am Harz. Unpublished diploma thesis, Universität Göttingen

Baier J, Negendank JFW, Zolitschka B (2003) Mid- to Late Holocene lake ecosystem response to catchment and climatic changes - a detailed varve analysis of Lake Holzmaar (Germany). In: Fischer H, Flöser G, Kumke T, Lohmann G, Miller G, Negendank JFW, von Storch H (eds) The KIHZ project: towards a synthesis of Holocene proxy data and climate models. Springer, Berlin, pp 197-210

Baier J, Lücke A, Negendank JFW, Schleser G-H, Zolitschka B (2004) Diatoms and geochemical evidence of mid- to late Holocene climatic changes at Lake Holzmaar, West-Eifel (Germany). Quat Int 113:81-96

Bartens H (1990) Untersuchungen über die Vegetationsgeschichte des Bruchberges im Oberharz. Unpublished diploma thesis, Universität Göttingen

Battarbee RW (1986) Diatom analysis. In: Berglund BE (ed) Handbook of holocene palaeoecology and palaeohydrology. Wiley, Chichester, pp 527-570

Behre KE (1978) Die Klimaschwankungen im europäischen Präboreal. Petermanns Geogr Mitt 2:97-107

Behre KE (1995) Vom Naturraum zur Kulturlandschaft10000 Jahre Umweltveränderungen durch den Menschen. VU Uitgeverij, Amsterdam 
Bennion H, Juggins S, Anderson NJ (1996) Predicting epilimnetic phosphorus concentrations using an improved diatom-based transfer function and its application to lake eutrophication management. Environ Sci Technol 30:2004-2007

Berglund BE (2001) Cultural landscape changes in NW Europe. Is there a link to climate changes? Terra Nostra 2001/ 3:68-75

Beug HJ (1957) Untersuchungen zur spätglazialen und frühpostglazialen Floren- und Vegetationsgeschichte einiger Mittelgebirge (Fichtelgebirge, Harz und Rhön). Flora 145: 167-211

Beug HJ (1961) Leitfaden der Pollenbestimmung. Fischer, Stuttgart

Beug HJ (1992) Vegetationsgeschichtliche Untersuchungen über die Besiedlung im Unteren Eichsfeld, Landkreis Göttingen, vom frühen Neolithikum bis zum Mittelalter. N Ausgr Forsch Niedersachsen 20:261-339

Beug HJ, Henrion I, Schmüser A (1999) Landschaftsgeschichte im Hochharz. Die Entwicklung der Wälder und Moore seit dem Ende der letzten Eiszeit. Papierflieger, ClausthalZellerfeld

Björck S, Muscheler R, Kromer B, Andresen CS, Heinemeier J, Johnsen SJ, Conley D, Koc N, Spurk M, Veski S (2001) High-resolution analyses of an early Holocene climate event may imply decreased solar forcing as an important climate trigger. Geology 29:1107-1110

Bond G, Kromer B, Beer J, Muscheler R, Evans MN, Showers W, Hoffmann S, Lotti-Bond R, Hajdas I, Bonani G (2001) Persistent solar influence on North Atlantic climate during the Holocene. Science 294:2130-2136

Bradbury JP (1975) Diatom stratigraphy and human settlement in Minnesota. Geol Soc Am, Special Paper 171:1-74

Bradbury JP, Dieterich-Rurup KV (1993) Holocene climate paleolimnology of Elk Lake, Minnesota. Geol Soc Am, Special Paper 276:215-237

Brauer A, Litt T, Negendank JFW, Zolitschka B (2001) Lateglacial varve chronology and biostratigraphy of lakes Holzmaar and Meerfelder Maar, Germany. Boreas 30:83-88

Chen SH (1982) Neue Untersuchungen über die spät- und postglaziale Vegetationsgeschichte im Gebiet zwischen Harz und Leine. Dissertation, Universität Göttingen

Chen SH (1988) Neue Untersuchungen über die spät- und postglaziale Vegetationsgeschichte im Gebiet zwischen Harz und Leine (BRD). Flora 181:147-177

Dansgaard W, White JWC, Johnsen SJ (1989) The abrupt termination of the Younger Dryas climate event. Nature 339:532-534

Denys L (1991) A check-list of the diatoms in the Holocene deposits of the western Belgian coastal plain with a survey of their apparent ecological requirements. I. Introduction, ecological code and complete list. Belgische Geol Dienst, Professional Paper 246:1-41

Digerfeldt G (1998) Reconstruction of Holocene lake-level changes in southern Sweden: technique and results. Paleoclim Res 25:87-98

Dixit S, Dickman MD (1986) Correlation of surface sediment diatoms with the present lake water $\mathrm{pH}$ in 28 Algoma lakes, Ontario, Canada. Hydrobiologia 131:133-143

Ellenberg H (1996) Vegetation Mitteleuropas mit den Alpen. Ulmer, Stuttgart
Emerson S, Bender M (1981) Carbon fluxes at the sedimentwater interface of the deep sea-calcium-carbonate preservation. J Marine Res 39(1):139-162

Eronen M, Hyvärinen H, Zetterberg P (1999) Holocene humidity changes in northern Finnish Lapland inferred from lake sediments and submerged Scots pines dated by tree-rings. Holocene 95:569-580

Eusterhues K, Lechterbeck J, Schneider J, Wolf-Brozio U (2002) Late- and post-glacial evolution of Lake Steisslingen (I) Sedimentary history, palynological record and inorganic geochemical indicators. Palaeogeogr Palaeoclimat Palaeoecol 187:341-371

Eusterhues K, Heinrichs H, Schneider J (2005) Geochemical response on redox fluctuations in Holocene lake sediments, Lake Steisslingen, Southern Germany. Chem Geol 222:1-22

Fægri K, Kaland PE, Krzywinski K (1989) Textbook of pollen analysis. Wiley, Chichester

Fahnenstiel GL, Glime JM (1983) Subsurface chlorophyll maximum and associated Cyclotella pulse in Lake Superior. Int Revue Ges Hydrobiol 68:605-616

Firbas F (1949) Spät- und nacheiszeitliche Waldgeschichte Mitteleuropas nördlich der Alpen. 1. Band: Allgemeine Waldgeschichte. Fischer, Jena

Firbas F (1952) Spät- und nacheiszeitliche Waldgeschichte Mitteleuropas nördlich der Alpen. 2. Band: Waldgeschichte der einzelnen Landschaften. Fischer, Jena

Fritz SC, Kingston JC, Engstrom DR (1993) Quantitative trophic reconstruction from sedimentary diatom assemblages: a cautionary tale. Freshwater Biol 30:1-23

Gächter R, Müller B (2003) Why the phosphorus retention of lakes does not necessarily depend on the oxygen supply to their sediment surface. Limnol Oceanogr 48:929-933

Glässer R (1994) Das Klima des Harzes. Kovac, Hamburg

Haas JN (1994) First identification key for charophyte oospores from central Europe. Eur J Phycol 29:227-235

Haas JN, Richoz I, Tinner W, Wick L (1998) Synchronous Holocene climatic oscillations recorded on the Swiss Plateau and at timberline in the Alps. Holocene 83: 301-309

Hammarlund D, Björck S, Buchardt B, Thomsen CT (2005) Limnic responses to increased effective humidity during the 8200 cal yr BP cooling event in southern Sweden. J Paleolimnol 34:471-480

Hausmann S, Lotter AF, van Leeuwen JFN, Ohlendorf C, Sturm M (2001) The influence of land-use and climate change on Alpine lakes: a high-resolution case study focusing on the past 1,000 years. Terra Nostra 2001/3: 96-99

Haworth EY (1976) Two Late-Glacial (Late Devensian) diatom assemblage profiles from northern Scotland. New Phytol 77:227-256

Hickel B, Hakansson H (1993) Stephanodiscus alpinus in Plußsee, Germany, ecology, morphology and taxonomy in combination with initial cells. Diatom Res 8:89-98

Hinze C, Meischner D (1968) Gibt es rezente Rotsedimente in der Adria? Mar Geol 6:53-71

Hofmann G (1994) Aufwuchs-Diatomeen in Seen und ihre Eignung als Indikatoren der Trophie. Bibl Diatomol 30: $1-241$

Hofmann G (1999) Trophiebewertung von Seen anhand von Aufwuchsdiatomeen. In: von Tümpling W, Friedrich G 
(eds) Methoden der Biologischen Wasseruntersuchung. Band 2: Biologische Gewässeruntersuchung. Fischer, Stuttgart

Hofmann G, Schaumburg J (2005a) Seelitorale in Bayern: Chiemsee und Königssee. Untersuchung benthischer Diatomeen 1994. Materialienband Bayerisches Landesamt Wasserwirtschaft 117:1-75

Hofmann G, Schaumburg J (2005b) Seelitorale in Bayern: Walchensee. Untersuchung benthischer Diatomeen 1995. Materialienband Bayerisches Landesamt Wasserwirtschaft 118:1-54

Hofmann G, Schaumburg J (2005c) Seelitorale in Bayern: Starnberger See. Untersuchung benthischer Diatomeen 1997. Materialienband Bayerisches Landesamt Wasserwirtschaft 119:1-74

Hofmann G, Schaumburg J (2005d) Seelitorale in Bayern: Ammersee. Untersuchung benthischer Diatomeen 2001. Materialienband Bayerisches Landesamt Wasserwirtschaft 120:1-75

Hofmann G, Schaumburg J (2005e) Seesedimente in Bayern: Waginger-Tachinger See. Diatomeenflora in Sedimentkernen. August 2002. Materialienband Bayerisches Landesamt Wasserwirtschaft 121:1-77

Hofmann G, Schaumburg J (2005f) Seesedimente in Bayern: Simssee. Diatomeenflora in Sedimentkernen. Dezember 2002. Materialienband Bayerisches Landesamt für Wasserwirtschaft 123:1-55

Hormes A, Müller BU, Schlüchter C (2001) The Alps with little ice: evidence for eight Holocene phases of reduced glacier extent in the Central Swiss Alps. Holocene 113:255-265

Hürlimann J, Schanz F (1993) The effects of artificial ammonium enhancement on riverine periphytic diatom communities. Aquat Sci 55:40-64

Kalis AJ, Merkt J, Wunderlich J (2003) Environmental changes during the Holocene climatic optimum in central Europe-human impact and natural causes. Quat Sci Rev 22:33-79

Kelly MG, Whitton BA (1995) The trophic diatom index: a new index for monitoring eutrophication in rivers. J Appl Phycol 7:433-444

Kilham P, Kilham SS, Hecky RE (1986) Hypothesized resource relationships among African planktonic diatoms. Limnol Oceanogr 31:1169-1181

Kilian MR, van der Plicht J, van Geel B (1995) Dating raised bogs: new aspects of AMS ${ }^{14} \mathrm{C}$ wiggle matching, a reservoir effect and climatic change. Quat Sci Rev 14: 959-966

Kleinmann A, Merkt J, Müller H (2000a) Climatic lake-level changes in German lakes during the Holocene? Terra Nostra 2000/7:55-63

Kleinmann A, Merkt J, Müller H, Küster H (2000b) Holocene lake-level changes in N- and S-Germany. In: Andres W (ed) Final Colloquium of the DFG priority programme "Changes of the Geo- Biosphere during the last 15.000 years", http://web.uni-frankfurt.de/fb11/ipg/spp/ Postergallery/Poster_gif/Poster_Kleinmann_etal.gif, Bonn

Komárek J, Fott B (1983) Chlorophyceae (Grünalgen). Ordnung: Chlorococcales. In: Huber-Pestalozzi G (ed) Das Phytoplankton des Süßwassers. Systematik und Biologie. Schweizerbart, Stuttgart
Köster D, Pienitz R (2006) Seasonal diatom variability and paleolimnological inferences - a case study. J Paleolimnol 35:395-416

Krammer K, Lange-Bertalot H (1986-1991) Süßwasserflora von Mitteleuropa, Bacillariophyceae-2/1 Naviculaceae, 2/2 Bacillariaceae Epithemiaceae Surirellaceae, 2/3 Centrales Fragilariaceae Eunotiaceae, 2/4 Achnanthaceae. Fischer, Stuttgart

Kristiansen J (2005) Golden algae. A biology of chrysophytes. Gantner, Ruggell

Lambert AM, Hsü KJ (1979) Varve-like sediments of the Walensee Switzerland. In: Schlüchter C (ed) Moraines and varves. Balkema, Rotterdam, pp 287-294

Lange-Bertalot H (1993) 85 neue Taxa und über 100 weitere neu definierte Taxa ergänzend zur Süßwasserflora von Mitteleuropa. Bibl Diatomol 27:1-454

Lange-Bertalot H, Metzeltin D (1996) Indicators of oligotrophy. Iconographia Diatomol 2:1-390

Lange-Bertalot H, Moser G (1994) Brachysira. Monographie der Gattung. Bibl Diatomol 29:1-212

Lechterbeck J (2000) "Human Impact" oder "Climatic Change"? Zur Vegetationsgeschichte des Spätglazials und Holozäns in hochauflösenden Pollenanalysen laminierter Sedimente des Steißlinger Sees (Südwestdeutschland). Dissertation, Universität Tübingen

Lotter AF, Bigler C (2000) Do diatoms in the Swiss Alps reflect the length of ice-cover? Aquat Sci 62:125-141

Lotter AF, Eicher U, Siegenthaler U, Birks HJB (1992) Lateglacial climatic oscillations as recorded in Swiss lake sediments. J Quat Sci 7:187-204

Lotter AF, Birks H, John B, Hofmann W, Marchetto A (1998) Modern diatom cladocera, chironomid, and chrysophyte cyst assemblages as quantitative indicators for the reconstruction of past environmental conditions in the Alps. II Nutrients. J Paleolimnol 19:443-463

Lücke AG, Schleser B, Zolitschka, Negendank J (2003) A Late Glacial and Holocene organic carbon isotope record of lacustrine palaeoproductivity and climatic change derived from varved lake sediments of Lake Holzmaar, Germany. Quat Sci Rev 22:569-580

Magny M (2004) Holocene climate variability as reflected by mid-European lake-level fluctuations and its probable impact on prehistoric human settlements. Quat Int 113:65-79

Maise C (1998) Archäoklimatologie-Vom Einfluss nacheiszeitlicher Klimavariabilität in der Ur- und Frühgeschichte. Jahrb Schweiz Ges Ur- und Frühgeschichte 81:197-235

Marciniak B (1986) Late Quaternary diatoms in the sediments of Przedni Staw Lake (Polish Tatra Mountains). Hydrobiologia 143:225-265

Meischner D, Torunski H, Kuhn G (1981) High-energy pneumatic vibration corer for subaqueous sediments. Senckenberg marit 12:179-187

Melzer A (1999) Aquatic macrophytes as tools for lake management. Hydrobiologia 395/396:181-190

Merkt J (1971) Zuverlässige Auszählungen von Jahresschichten in Seesedimenten mit Hilfe von Groß-Dünnschliffen. Arch Hydrobiol 69:145-154

Mohr K (1982) Harzvorland, westlicher Teil. Sammlung Geol Führer 70:1-155 
Moore PD, Webb JA, Collinson ME (1991) Pollen analysis. Blackwell, Oxford

Morse JW, Mackenzie FT (1990) Geochemistry of sedimentary carbonates. Dev Sedimentol 48:1-707

Nesje A, Dahl SO, Andersson C, Matthews JA (2000) The lacustrine sedimentary sequence in Sygneskardvatnet, western Norway: a continuous, high-resolution record of the Jostedalsbreen ice cap during the Holocene. Quat Sci Rev 19:1047-1065

Oberdorfer E (1994) Pflanzensoziologische Exkursionsflora. Ulmer, Stuttgart

Priesnitz K (1969) Kurze Übersicht über den Karstformenschatz des südwestlichen Harzrandes. Jahrb Karst- und Höhlenkde 9:11-23

Raeder UBC (1990) Vergleichende Untersuchungen der Phytoplanktonsukzession in 15 Seen des Osterseegebietes. Dissertation, Universität München

Rautio M, Sorvari S, Korhola A (2000) Diatom and crustacean zooplankton communities, their seasonal variability and representation in the sediments of subarctic Lake Saanajärvi. J Limnol 59(Suppl 1):81-96

Reichardt E, Lange-Bertalot H (1991) Taxonomische Revision des Artenkomplexes um Gomphonema angustum-G dichotonum $-\mathrm{G}$. intricatum $-\mathrm{G}$. vibrio und ähnliche Taxa (Bacillariophyceae). Nova Hedwigia 53:519-544

Reimann I (1998) Experimentelle Studien am Diatomeenaufwuchs. Autökologische und mikrobiologische Aspekte der Trophieindikation. Dissertation, Universität München

Reynolds CS (1984) The ecology of freshwater phytoplankton. Cambridge University Press, Cambridge

Rioual P (2000) Diatom assemblages and water chemistry of lakes in the French Massif Central: a methodology for reconstruction of past limnological and climate fluctuations during the Eemian period. Dissertation, University College London

Röthlisberger F (1986) 10000 Jahre Gletschergeschichte der Erde. Sauerländer, Aarau

Round FG (1981) The ecology of algae. Cambridge University Press, Cambridge

Round FE, Brook AJ (1959) The phytoplankton of some Irish loughs and an assessment of their trophic status. Proc R Irish Acad 60:167-191

Saarnisto M (1986) Annually laminated lake sediments. In: Berglund BE (ed) Handbook of Holocene palaeoecology and palaeohydrology. Wiley, Chichester, pp 343-370

Scheffler W (1994) Cyclotella pseudocomensis Nov. Sp. (Bacillariophyceae) aus norddeutschen Seen. Diatom Res 9:355-369

Schlichtherle H, Hasenfratz A, Geisser H, Billamboz A, Dieckmann B, Ellminger F, Gollnisch-Moos H, Haas J-N, Maier U, Tegel W, Vogt R, Wehrli M (2000) Changes of landscape and settlement patterns in the western Lake of Constance area. In: Andres W (ed) Final Colloquium of the DFG priority programme "Changes of the Geo-Biosphere during the last 15.000 years", http://web.uni-frankfurt.de/fb11/ ipg/spp/Postergallery/Poster_gif/Poster_Schlichtherle.gif, Bonn

Schmidt R, Kamenik C, Roth M (2007) Siliceous algae-based seasonal temperature inference and indicator pollen tracking ca. 4,000 years of climate/land use dependency in the southern Austrian Alps. J Paleolimnol 38:541-554

Seppä H, Birks HJB (2001) July mean temperature and annual precipitation trends during the Holocene in the Fennoscandian tree-line area: pollen-based climate reconstructions. Holocene 11:527-539

Smol JP (1983) Paleophycology of a high arctic lake near Cape Herschel, Ellesmere Island. Can J Bot 61:2195-2204

Smol JP (1988) Paleoclimate proxy data from freshwater arctic diatoms. Verh Internat Verein Limnol 837-844

Smol JP, Cumming BF (2000) Tracking long-term changes in climate using algal indicators in lake sediments. J Phycol 36:986-1011

Sommer U (1987) Factors controlling the seasonal variation in phytoplankton species composition-a case study for a deep nutrient rich lake. Progr Phycol Res 5:123-178

Sommer U (1994) Planktologie. Springer, Heidelberg

Spurk M, Leuschner HH, Baillie MGL, Briffa KR, Friedrich M (2002) Depositional frequency of German subfossil oaks: climatically and non-climatically induced fluctuations in the Holocene. Holocene 12:707-715

Stoermer EF (1984) Some perspectives on diatom ecology. Ann Bot 52:549-563

Stoermer EF (1993) Evaluating diatom succession: some peculiarities of the Great Lakes case. J Paleolimnol 8: $71-83$

Stoermer EF, Yang JJ (1970) Distribution and relative abundance of dominant plankton diatoms in Lake Michigan. University of Michigan, Great lakes research division publication no. 16, Ann Arbor

Stuiver M, Reimer PJ, Bard E, Beck JW, Burr GS, Hughen KA, Kromer B, McCormac G, van der Plicht J, Spurk M (1998) INTCAL 98 radiocarbon calibration 24,000—0 cal BP. Radiocarbon 40:1041-1083

Teichmann F (1986) Der Jues-See: Limnogeologische Untersuchung eines Erdfallsees am Südwestrand des Harzes. Unpublished diploma thesis, Universität Göttingen

ter Braak CJF, Juggins S (1993) Weighted averaging partial least square regression (WA-PLS): an improved method for reconstructing environmental variables from species assemblages. Hydrobiologia 269/270:485-502

ter Braak CJF, van Dam H (1989) Inferring pH from diatoms: a comparison of old and new calibration methods. Hydrobiologia 178:209-223

Thürnau K (1913) Der Zusammenhang der Rhumequelle mit der Oder und Sieber. Jahrb Gewässerkunde Norddeutschlands, Bes Mitt 2(6):1-25

Tilman D, Kilham SS, Kilham P (1982) Phytoplankton community ecology: the role of limiting nutrients. Annu Rev Ecol Syst 13:349-372

Tinner W, Lotter AF, Ammann B, Conedera M, Hubschmid P, van Leeuwen JFN, Wehrli M (2003) Climatic change and contemporaneous land-use phases north and south of the Alps 2300 BC to 800 AD. Quart Sci Rev 22:1447-1460

van Dam H, Mertens A, Sinkeldam J (1994) A coded checklist and ecological indicator values of freshwater diatoms from the Netherlands. Netherlands $J$ Aquatic Ecol 28:117-133

van Geel B, Berglund BE (2000) A causal link between a climatic deterioration around $850 \mathrm{cal} \mathrm{BC}$ and a subsequent 
rise in human population density in NW-Europe? Terra Nostra 2000/7:126-130

van Geel B, Buurmann J, Waterbolk HT (1996) Archaeological and palaeoecological indications of an abrupt climate change in The Netherlands and evidence for climatological teleconnections around 2650 BP. J Quat Sci 11: 451-460

van Geel B, Raspopov OM, Renssen H, van der Plicht J, Dergachev VA, Meijer HAJ (1999) The role of solar forcing upon climate change. Quat Sci Rev 18:331-338

van Geel B, Bokovenko NA, Burova ND, Chugunov KV, Dergachev VA, Dirksen VG, Kulkova M, Nagler A, Parzinger H, van der Plicht J, Vasiliev SS, Zaitseva GI (2004) Climate change and the expansion of the Scythian culture after 850 BC: a hypothesis. J Archaeol Sci 31: 1735-1742

Voigt R (1996) Paläolimnologische und vegetationsgeschichtliche Untersuchungen an Sedimenten aus Fuschlsee und Chiemsee (Salzburg und Bayern). Diss Bot 270:1-303

Voigt R (2006) Settlement history as reflection of climate change- the case study Lake Jues (Harz Mountains Germany). Geogr Ann 88A(2):1-9

Vollenweider RA (1979) Das Nährstoffbelastungskonzept als Grundlage für den externen Eingriff in den Eutrophierungsprozeß stehender Gewässer und Talsperren. Z Wasser- und Abwasser-Forschung 2/79:46-56

Von Grafenstein U, Erlenkeuser H, Müller J, Jouzel J, Johnsen S (1998) The cold event 8200 years ago documented in oxygen isotope records of precipitation in Europe and Greenland. Clim Dyn 14:73-81

Von Grafenstein U, Erlenkeuser H, Brauer A, Jouzel J, Johnsen SJ (1999) A mid-european decadal isotope-climate record from 15,500 to 5000 Years BP. Science 284:1654-1657

Wennrich V (2005) Die spätweichselglaziale und holozäne Klima- und Umweltgeschichte des Mansfelder Landes / Sachsen-Anhalt, abgeleitet aus Seesedimenten des ehemaligen Salzigen Sees. Dissertation, Universität Leipzig

Whitmore TJ (1989) Florida diatom assemblages as indicators of trophic state and pH. Limnol Oceanogr 34:882-895
Winkler LW (1888) Die Bestimmung des im Wasser gelösten Sauerstoffs und die Löslichkeit des Sauerstoffs im Wasser. Berichte der Deutschen Chemischen Gesellschaft 21:2843-2854

Witkowski A, Lange-Bertalot H, Metzeltin D (1995/96) The diatom species Fragilaria martyi (Heribaud) LangeBertalot, identity and ecology. Arch Protistenkde 146: 281-292

Wolfe AP (1997) On diatom concentrations in lake sediments: results from an inter-laboratory comparison and other tests performed on a uniform sample. J Paleolimnol 18:261-268

Wolin JA, Stoermer EF, Schelske CL, Conley DJ (1988) Siliceous microfossil succession in the recent Lake Huron sediments. Arch Hydrobiol 114:175-198

Wunsam S, Schmidt R (1995) A diatom-phosphorus transfer function for alpine and pre-alpine lakes. Mem Ist Ital Idrobiol 53:85-99

Wunsam S, Schmidt R, Klee R (1995) Cyclotella-taxa (Bacillariophyceae) in alpine lakes and their relationship to environmental variables. Aquat Sci 57:360-386

Zelinka M, Marvan P (1961) Zur Präzisierung der biologischen Klassifikation der Reinheit fließender Gewässer. Arch Hydrobiol 57:389-407

Zolitschka B (1998) Paläoklimatische Bedeutung laminierter Sedimente. Relief Boden Paläoklima 13:1-176

Zolitschka B, Negendank J FW (1997) Climate change at the end of the third millenium $\mathrm{BC}$-evidence from varved lacustrine sediments. NATO ASI Series I 49:679-690

Zolitschka B, Brauer A, Negendank JFW, Stockhausen H, Lang A (2000) Annually dated late Weichselian continental paleoclimate record from the Eifel, Germany. Geol 28/9:783-786

Zolitschka B, Behre KE, Schneider J (2003) Human and climatic impact on the environment as derived from colluvial, fluvial and lacustrine archives-examples from the Bronze Age to the Migration period, Germany. Quat Sci Rev 22:81-100 